\title{
LEAVING THE PRACTICE OF LAW: THE WHEREFORES AND THE WHYS ${ }^{1}$
}

\section{JOAN BROCKMAN*}

In 1990, the Benchers of the Law Society of Alberta established a Committee on Women and the Legal Profession to examine the issues concerning women in the law. This article examines the results of a comprehensive survey conducted on inactive members of the Law Society of Alberta for this Committee. The survey was the second of two surveys conducted by this author. The first survey was conducted on the active members of the Law Society of Alberta.

The survey produced a number of interesting results for those individuals considering the practise of law as a profession and for those already within the profession. The survey looked at the characteristics of the respondents, their reasons for leaving the practise of law, and their perceptions and experience with bias within the profession. A useful section of the survey included suggestions for reforming the legal profession and the Law Society of Alberta itself.
En 1990, les membres du Barreau de l'Alberta ont fondé un comité chargé d'étudier les questions relatives aux femmes dans les carrières juridiques. Le présent article examine les résultats d'une enquête exhaustive effectuée pour ce comité, auprès des membres inactifs de la Law Society of Alberta. II s'agissait de la deuxième étude du genre effectuée par l'auteure. La première enquête ciblait les membres actifs du Barreau.

L'enquête a permis d'obtenir un certain nombre de résultats intéressants pour les personnes qui envisagent de faire carrière en droit et pour celles qui pratiquent déjà. Elle a examiné les caractéristiques des personnes interrogées, les raisons qui les ont motivé à renoncer à la pratique du droit, et leurs perceptions et expériences en matière de préjugés au sein de la profession. Une section utile de l'enquête suggère certaines réformes à apporter dans les carrières juridiques et la Law Society of Alberta elle-mème.

\section{TABLE OF CONTENTS}

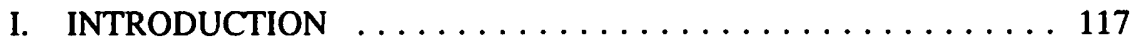

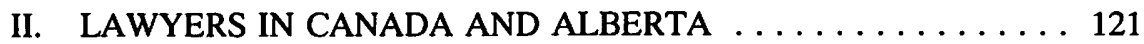

A. GROWTH IN THE NUMBER OF

LAWYERS IN CANADA . . . . . . . . . . . . . . 121

B. GROWTH IN THE NUMBER OF

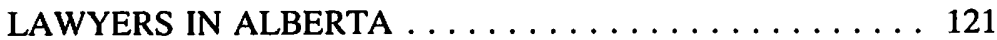

C. NUMBER OF LAWYERS IN ALBERTA AND

TYPE OF EMPLOYMENT $\ldots \ldots \ldots \ldots \ldots \ldots \ldots \ldots \ldots \ldots$

D. ADMISSIONS TO AND GRADUATES FROM

ALBERTA LAW SCHOOLS $\ldots \ldots \ldots \ldots \ldots \ldots \ldots \ldots \ldots$

School of Criminology, Simon Fraser University, Burnaby, British Columbia, V5A 1S6. Member of the Law Societies of British Columbia and Alberta (non-practising).

1 This paper is based on a survey of non-practising members of the Law Society of Alberta which was conducted for the Law Society's Committee on Gender Inequality in the Legal Profession. The views expressed in this paper are those of the author, and do not necessarily reflect the views of the Committee or the Law Society. I would like to thank the non-practising members who took the time to respond to this survey and members of the Committee on Gender Inequality for their assistance in drafting the questionnaire used in this study and for their comments on an earlier draft of my report to them. I am grateful to Peter Freeman, Q.C., Secretary of the Law Society and Dianne Ennis and Nona Klassen, staff at the Law Society, for coordinating the survey. I also thank Bill Glackman for statistical and technical support and V. Gordon Rose for his editorial comments. The financial support of the Law Society of Alberta is gratefully acknowledged. 
III. LAWYERS LEAVING THE PRACTICE OF

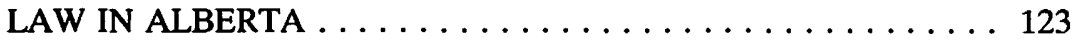

IV. A SURVEY OF NON-PRACTISING MEMBERS

OF THE LAW SOCIETY OF ALBERTA . . . . . . . . . . . . 124

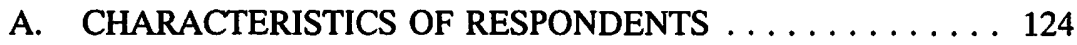

B. LEAVING THE PRACTICE OF LAW:

WHERE ARE THEY NOW? . . . . . . . . . . . . . 125

C. GENDER BIAS IN THE LEGAL PROFESSION . . . . . . 134

D. PERSONAL EXPERIENCE WITH BIAS

OR DISCRIMINATION . . . . . . . . . . . . . . . . . . 139

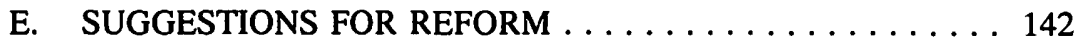

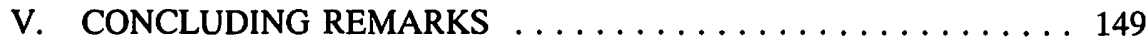

A. INFLEXIBILITY IN THE LEGAL PROFESSION $\ldots \ldots \ldots 149$

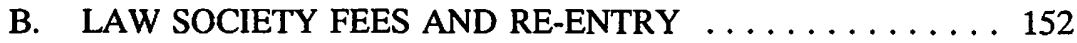

C. DISCRIMINATION IN THE LEGAL PROFESSION $\ldots \ldots \ldots 152$

D. ALTERNATIVE CAREERS FOR LAWYERS . . . . . . . 153

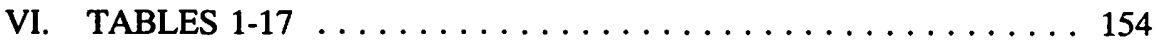

VII. APPENDIX A: THE QUESTIONNAIRE $\ldots \ldots \ldots \ldots \ldots \ldots 176$

\section{INTRODUCTION}

Reasons why lawyers leave the practice of law might be classified simplistically as "the good, the bad and the ugly." For some lawyers, law is a good stepping stone to other more rewarding or lucrative careers. ${ }^{2}$ For bad lawyers, the law might lead to suspension or disbarment. Fraud by lawyers on their clients has been linked with the stressful nature of the practice of law and its accompanying lifestyle pressures. ${ }^{3}$ For others lawyers, the practice of law is a "'cesspool', a 'den of iniquity' and more often than anything else, 'ugly'." ${ }^{4}$ Some of these lawyers leave the practice of law, ${ }^{5}$ while others continue in the

See R. Ray, "Ted Horton, A Natural Departure" (April, 1993) National 16; J. Flemming, "His Brilliant Career, Part 2" (May, 1990) Report on Business 29; M. Zwicker, "Finding Happiness Outside the Practice of Law" (February, 1992) National 25 who discusses Mary Ann Altman's book Life After Law: Second Careers For Lawyer (Washington: Wayne Smith Company, 1991). See also D. Arron, What Can You Do With a Law Degree? A Lawyer's Guide to Career Alternatives Inside, Outside and Around the Law (Washington: Niche Press, 1992).

L. Korbin, "Depression and Lawyers: A Research Study" (June/July, 1991) Newsletter at 7 writes, "We know that substance abuse and psychological distress are contributing factors in many disciplinary cases." Also see P. McLaughlin, "Forensic Accounting: Tales of Greed \& Cunning" (April, 1993) National 20 at 22.

M. Otvos, "Why I'm Leaving Law" (February, 1992) Can. Law. 12 at 16.

Leaving law is not an easy proposition. Deborah Arron, a former American practitioner, uses a prison analogy to describe how lawyers get out of the practice of law. The titles of her chapters are: "Prison Unrest", "The Scene of the Crime", "The Runner's Profile", "Up Against the Wall", "Making the Break", "Assuming a New Identity", "No Remorse", "Coping With the Law," and "Rehabilitating the System." Dissatisfaction within the legal profession has long been a taboo topic suppressed by a conspiracy of silence, which has to some extent been broken by career counsellors and by books directed at assisting dissatisfied lawyers to leave the profession. See D. Arron, Running From the Law: Why Good Lawyers are Getting Out of the Legal Profession (Seattle: Niche Press, 1989). More recently a former lawyer from Ontario compared the practice of law in a large Toronto firm to a religious cult, which made it that much more difficult for her to leave. "Why I'm Leaving Law," ibid. 
den and ease the stress by resorting to drugs, whether they are legal or illegal. ${ }^{6}$ The Law Society of Alberta, as well as other law societies across Canada, have established programs to assist lawyers who have problems related to stress and drug-use. ${ }^{7}$

This simplistic framework for explaining why lawyers are leaving the practice of law is complicated by the increasing number of women in the legal profession, and the workforce more generally. The traditional line between public and private lives is being erased. ${ }^{8}$ Historically, the typical male lawyer relied on a full-time spouse to organize his home, family, work, and other aspects of his life. With the increasing number of women entering the paid workforce, ${ }^{9}$ there are fewer women who confine their work to these supportive roles. ${ }^{10}$ For women lawyers, a stay-at-home spouse is rare. ${ }^{11}$ Increasingly,

at 13.

6 J. Mucalov, "The Stress Epidemic: Succumbing to the Pressures of Practice in the 90s" (May, 1993) Can. Law. 18; G. Bellett, "Stressed for Success: the High-Octane Life of Lawyers" Vancouver Sun (10 October 1992) B1; McLaughlin, supra note 3 at 25. A survey of lawyers by Joan Brewster for the Addiction Research Foundation of Ontario found that almost one-third were "problem drinkers" (defined as one of the following happening at least once a month: calling in sick, showing up late for work, drinking during work, or facing criticism by family and friends about their drinking), $20 \%$ were frequent drinkers (using alcohol at least 20 days each month), $8 \%$ had used marijuana in the last year, and $2 \%$ were regular users of narcotics. See K. LaPointe, "Study Cites Drugs, Liquor use among MDs, Lawyers" Vancouver Sun (7 June 1993) A2. Also see, "Depression and Lawyers" supra note 3 at 7 for a summary of a study on depression and alcoholism among Washington lawyers. In Alberta, the Office of the Practice Advisor, along with the Mentor Program and the Lawyers Assistance Program (ASSIST) assist lawyers with a variety of problems. See the regular reports by Barry Vogel, Q.C. "From the Office of the Practice Advisor" in the Law Society of Alberta's Newsletter.

For many women this line never existed. For a summary of the history of women's participation in the paid workforce see A. Duffy \& N. Pupo, Part-Time Paradox: Connecting Gender, Work and Family (Toronto: McClelland \& Stewart, 1992) chapter 1; Stephen G. Peitchinis, Women at Work: Discrimination and Response (Toronto: McClelland \& Stewart, 1989). The contributions women make to the economy through their unpaid labour are further explored in P. Armstrong \& $\mathrm{H}$. Armstrong, Theorizing Women's Work (Toronto: Garamond Press, 1990) and M. Luxton, H. Rosenberg \& S. Arat-Koc, Through the Kitchen Window: The Politics of Home and Family (Toronto: Garamond Press, 1990).

In Canada in 1991, 68\% of women over the age of 15 , living in private households with children at home, were in the workforce (up from $52 \%$ in 1981). The labour force participation rate of women without children was $54 \%$. For women who were married, living with their spouse and had children at home the participation rate was $70 \%$ (up from $52 \%$ in 1981). If one limits this latter group to those with children under the age of 6 , the participation rate was $69 \%$ (up from $49 \%$ in 1981). Statistics Canada, Labour Force Activity of Women by Presence of Children (Ottawa: Statistics Canada, 1993) no. 93-325 at 8 and 16 [hereinafter Labour Force Activity] and Statistics Canada, The Daily (Ottawa: Statistics Canada, March 2, 1993) at 4.

In a survey of active members of the Law Society of Alberta in 1991, 28.3\% of the male respondents had spouses who were not employed, $22.4 \%$ had spouse who were employed part-time, $32.9 \%$ had spouses who were employed full time, and $16.4 \%$ were not living with a spouse. J. Brockman, "Bias in the Legal Profession: Perceptions and Experiences" (1992) 30:3 Alta. L. Rev. 747 [hereinafter "Bias in the Legal Profession"].

1 In the survey of Alberta active members, $4.7 \%$ of the women had spouses who were not employed, $2.0 \%$ had spouses who were employed part-time, $67.8 \%$ had spouses who were employed fulltime, and $25.5 \%$ were not living with a spouse. See "Bias in the Legal Profession" ibid. Having a stay-athome spouse does not necessarily translate into support for a working woman. See A. Hochschild with A. Machung, The Second Shift: Working Parents and the Revolution at Home (New York: 
the norm is for both spouses to work in the paid workforce. ${ }^{12}$ This increases the burden of raising children and managing the household chores on both spouses, however, women bear more of this additional burden than men. ${ }^{13}$

This shift in the work force calls for a greater balance between professional and private life in the legal profession. ${ }^{14}$ In addition, it calls for alterations in the structure of the profession for lawyers who want a more flexible work schedule ${ }^{15}$ or who want to leave the legal profession and re-enter at a later time. Law societies and their members have a vested interest in reducing the amount of stress in the practice of law, and in some cases, facilitating transitions to alternative careers. ${ }^{16}$

There is also a widespread perception in the legal profession that women lawyers encounter bias or discrimination based on gender. In a survey of active members of the Law Society of Alberta, $97.2 \%$ of the women and $77.6 \%$ of the men were of the view that there was some bias or discrimination against women in the legal profession. ${ }^{17}$ In a survey of members of the Law Society of British Columbia, $97.5 \%$ of the women and $83.4 \%$ of the men thought there was some bias or discrimination against women in the

Viking Penguin, 1989).

In 1991, the labour force participation rate of married women with spouses present in the home was 63\%. Labour Force Activity, supra note 9 at 16.

In the survey of active members of the Law Society of Alberta, women who worked full time and had children requiring care spent a median of 35 hours on such care, the men spent a median of 15 hours on such care. The women spent a median of 10 hours a week on household chores, the men spent a median of 8 hours. "Bias in the Legal Profession" supra note 10 at 761 . Similar results were found in a survey of active members of the Law Society of British Columbia. See J. Brockman, "Gender Bias in the Legal Profession: A Survey of Members of the Law Society of British Columbia" (1992) 17:1 Queen's L.J. 91 at 126-127 [hereinafter "Gender Bias"].

14 T.G. Sosa, "A Balance Between Professional and Private Life" (1990) 24:2 L. Soc. Gaz. 162; M.A. Gross, "Can We Re-humanize the Practice of Law?" (1990) 24:3 L. Soc. Gaz. 205; T. Perrin, "Balancing Lives: There's Little Help For Young Parents" (September, 1991) National 11; J.L. MacBridge-King \& H. Paris, Balancing Professional and Family Responsibilities: A Survey of Lawyers and Law Firms (Ottawa: Compensation Research Centre, The Conference Board of Canada, 1989). Some men later regret the lack of time spent with their children. Alec Robertson, who left the raising of his children, who are now in their thirties, to his spouse, said, "I followed the usual pattern of working nights and days until I reached the stage where I didn't know them very well. I look back on it and realize I wouldn't do that again. I missed out on valuable time with them." Quoted in J. Thompson, "Women in Law" (November/December, 1992) National 28 at 31.

The Law Society of Alberta, as well as other law societies, are implementing some of these changes. See B. Mahoney, "Changing Times - Workplace Options" (October/November, 1992) Newsletter 5. Seminars on "Equality in the Law Firm: A Practical Approach to Gender Issues," held in Calgary and Edmonton in March of 1993, addressed issues of parental leave and alternate work schedules. See "Equality in the Law Firm" (March, 1993) Benchers' Advisory at 7. The Benchers have also approved a document developed by the Committee on Gender Inequality in the Legal Profession entitled "Alternative Work Schedules Guidelines for Law Firms", Benchers' Advisory, ibid. at 1.

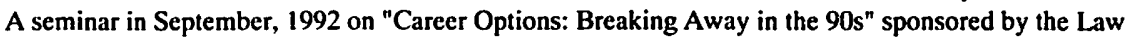
Society of Alberta and the Legal Education Society of Alberta was also designed to assist lawyers in alternative career plans. See B. Mahoney, "Changing Times - Career Options" (September, 1992) Newsletter 4; B. Mahoncy. "Changing Times: The Legal Profession in the Twenty-First Century" (December, 1992/January, 1993) Newsletter 10; and "Career Alternatives for Lawyers" (July, 1992) Benchers' Advisory at 1.

"Bias in the Legal Profession", supra note 10 at 755. 
legal profession. ${ }^{18}$ "Career advancement" was mentioned most frequently by women and men in both surveys as an area in which women are discriminated against. For example, $81.8 \%$ of the women and $42.4 \%$ of the men in the Alberta survey, ${ }^{19}$ and $75.5 \%$ of the women and $43.7 \%$ of the men in the British Columbia survey ${ }^{20}$ mentioned the area of career advancement.

A recent study in British Columbia has shown that women leave the practice of law in a greater proportion than men (although not in as great a number). It found that $22 \%$ of the women, as compared to only $13 \%$ of the men, called to the Bar between 1974 and 1988, were no longer members in 1990 . Despite the higher proportion of women leaving the profession, men represented $62 \%$ of those who had not renewed their memberships. ${ }^{21}$ A study in Saskatchewan found that 75 men (57\% of the total of 131) and 56 women (43\%) who had graduated from the College of Law, University of Saskatchewan between 1970 and 1990 and who resided in Saskatchewan, were non-practising members of the Law Society in 1991. If graduates of the University of Saskatchewan Law School who resided in the province, but were not listed as members of the Society are added to this group, there were 77 men ( $46 \%$ of the total) and 89 women (54\%) in the non-practising group. ${ }^{22}$ A study in Ontario found that while women represented $30 \%$ of those called to the Bar in Ontario between 1975 and 1990, they represented 37\% of those who were no longer practising law. ${ }^{23}$

In April of 1990, the Benchers of the Law Society of Alberta established a Committee on Women and the Legal Profession to research and review issues concerning women in the profession. ${ }^{24}$ This paper discusses the results of the second of two surveys conducted for the Committee, ${ }^{25}$ the purpose of which was to develop a descriptive profile of nonpractising members of the Law Society: Are they working? If so, where? Why have they not maintained their active status in the Law Society? What are their perceptions of, and experiences with, bias or discrimination in the legal profession? What, if anything, do they think the Law Society and the legal profession ought to do to accommodate their needs?

Part II of this paper examines the statistical data regarding the number of women and men in the legal profession in Canada between 1986 to 1991, and in Alberta between 1915 and 1991. Part III examines the attrition rates of women and men from active status

18 "Gender Bias", supra note 13 at 100.

19 "Bias in the Legal Profession", supra note 10 at 755.

2o "Gender Bias", supra note 13 at 104.

21 J. Brockman, "Resistance by the Club' to the Feminization of the Legal Profession" (1992) $7: 2$ Canadian Journal of Law and Society 47 at 58-59 [hereinafter "'Resistance by the Club"]. Committee on Gender Discrimination, A Study of Gender and the Legal Profession in Saskatchewan, 1990-91 by S. Robertson (Law Society of Saskatchewan: Regina, August 1992). See F. Kay, Transitions in the Ontario Legal Profession: A Survey of Lawyers Called to the Bar Between 1975 and 1990 (A Report of the Law Society of Upper Canada: May 1991) at 98. Committee on Gender and Inequality in the Legal Profession, which "better reflects the Committee's mandate"; Alberta Law Society, (July 1992) 27 Bencher's Advisory 1. 
with the Law Society of Alberta (as of 1991) called to the Bar in Alberta between 1936 and 1990.

Part IV describes the results of the survey of women and men residing in Alberta who had transferred to the non-practising list between 1987 and 1991, and who were on the inactive list when it was compiled in November, 1991. It describes where these members are, their reasons for transferring to the inactive list, and their perceptions and experiences with bias or discrimination in the legal profession in Alberta. This part also examines the respondents' suggestions for reforming the legal profession.

In conclusion, Part $\mathrm{V}$ of this paper summarizes some of the concerns expressed by the respondents in this survey, and examines some of the ways the Law Society of Alberta and other law societies are addressing them.

\section{LAWYERS IN CANADA AND ALBERTA}

\section{A. GROWTH IN THE NUMBER OF LAWYERS IN CANADA}

Table 1 shows that the number of lawyers in Canada grew by $28 \%$ between 1986 and $1991{ }^{26}$ Women increased their representativeness in the legal profession during this five year period from $21.8 \%$ to $29.1 \% .{ }^{27}$ During this time period the number of women lawyers increased by $71 \%,{ }^{28}$ as compared to a $16 \%$ increase in the number of men lawyers. Women made up $55.8 \%$ of the total increase in the number of lawyers between 1986 and $1991 .^{29}$

\section{B. GROWTH IN THE NUMBER OF LAWYERS IN ALBERTA ${ }^{30}$}

Since 1915, when Lillian Ruby Clements became the first woman called to the Bar in Alberta, ${ }^{31}$ the proportion of women lawyers in Alberta has grown to approximately $25 \%$ of lawyers. Table 2 shows that the number of lawyers in Alberta grew by $19 \%$ between

During this time period the population of Canada grew by $7.9 \%$, from $25,309,330$ to $27,296,855$, so that in 1991 there were 196 lawyers per 100,000 population, as compared to 166 lawyers per 100,000 population in 1986. Statistics Canada, Age, Sex and Marital Status (Ottawa: Statistics Canada, 1993) no. 93-310 at 6.

This was up from $15.5 \%$ in 1981 and $5.2 \%$ in 1971. See "'Resistance by the Club'", supra note 21 at 52 .

28 This was down from the 75\% increase between 1981 and 1986 and the 527\% increase between 1971 and 1981, ibid.

This was up from representing $51.2 \%$ of the increase between 1981 and 1986 and $24.9 \%$ of the increase between 1971 and 1981, ibid.

The number of members of the Law Society and the number of lawyers in Alberta according to Statistics Canada are different for a number of reasons. Membership in the Law Society is required to practise law, but not for many other careers engaged in by legally trained people, such as business, research, teaching and various forms of public service. Statistics Canada defines lawyers on the basis of the type of work they perform, and includes notaries in both Quebec and British Columbia. See Statistics Canada, Standard Occupational Classification (Ottawa: Statistics Canada, 1980) no. 12-565. Lillian Ruby Clements died on June 21, 1956. I am grateful to Dianne Ennis for providing this information from Lillian Ruby Clements' file at the Law Society of Alberta. 
1986 and $1991 .^{32}$ Women increased their representativeness in the legal profession during this five year period from $23.7 \%$ to $24.5 \%$. During this time period the number of women lawyers increased by $23 \%$, as compared to an $18 \%$ increase in the number of men lawyers. Women made up $28.8 \%$ of the total increase in the number of lawyers in Alberta between 1986 and 1991.

Table 3 shows the absolute and relative numbers of women and men called to the Bar in Alberta between 1915 and 1969. Figure 1 (data in Table 4) illustrates a year-by-year breakdown of the numbers of women and men called to the bar in Alberta between 1970 and 1991. It was not until 1975 that women started, with consistency, to make up over $10 \%$ of those called to the Bar. ${ }^{33}$ In 1983 women began to consistently represent over $25 \%$ of those called to the Bar in Alberta. In 1991, 38\% of those called to the bar were women.

\section{NUMBER OF LAWYERS IN ALBERTA AND TYPE OF EMPLOYMENT}

In 1991, there were 4,789 active members of the Law Society, of which $20.3 \%$ were women. Table 5 shows where these members were employed in the legal profession in Alberta as of May 1, 1991. Women were somewhat disproportionately represented in companies and corporations ( $16.0 \%$ of the women, as compared to $9.1 \%$ of the men) and government (11.3\% of the women, as compared to $6.7 \%$ of the men). Women were underrepresented in law firms (57.3\% of the women as compared to $68.2 \%$ of the men). Women and men were equally represented as sole practitioners or working with a sole practitioner.

\section{ADMISSIONS TO AND GRADUATES FROM ALBERTA LAW SCHOOLS}

Tables 6 and 7 show the number of women and men who were admitted to the law schools at the University of Calgary and the University of Alberta from the time such records were kept up until 1991. Women entered law school at the University of Calgary in equal proportion to men in 1979, and exceeded the proportion of men in five of the 14 years. In contrast, the largest proportion of women entering Law School at the University of Alberta was $45.5 \%$ in 1986 . The University of Calgary admitted its highest proportion of women in $1991(64.7 \%)$.

Tables 8 and 9 show the number of women and men who have graduated from the two law schools. The highest proportion of women $(56.7 \%)$ graduated from the University of

During this time period the population of Alberta grew by $7.6 \%$, from $2,365,825$ to $2,545,550$, so that in 1991 there were 200 lawyers per 100,000 population, as compared to 180 lawyers per 100,000 population in 1986. Statistics Canada, Age, Sex and Marital Status (Ottawa: Statistics Canada, 1993) no. 93-310 at 15. This brought Alberta back in line with the overall presence of lawyers in Canada. See supra note 25 . Alberta had the greatest increase in the number of lawyers in all of the provinces between 1971 and 1981 at $174 \%$, compared to the overall increase in Canada of $110 \%$. See D.A.A. Stager \& H. Arthurs, Lawyers in Canada (Toronto: University of Toronto Press, 1990) at 143-145. Prior to 1975 , women made up over $10 \%$ in the following years: $1923(17.1 \%$ of the 41 lawyers called), 1930 (20.0\% of the 10 lawyers called), 1944 (33.0\% of the 6 lawyers called) and 1971 (10.5\% of the 124 lawyers called). 
Calgary in 1991, and the highest proportion of women (46.0\%) graduated from the University of Alberta in 1989.

\section{LAWYERS LEAVING THE PRACTICE OF LAW IN ALBERTA}

In November of 1991, there were 145 women and 169 men on the non-practising list who resided in Alberta and who had transferred to the inactive list between 1987 and 1991. Women represented $46.2 \%$ of these lawyers.

This part of the paper examines the attrition rates, as of May 1,1991, of women and men called to the Bar in Alberta between 1936 (the year of call of the most senior member still active on May 1, 1991) and 1990. These statistics do not take into account any of the reasons why these members have moved to the non-practising list or left the Law Society completely. Reasons for moving to the non-practising list could include retirement, migration, loss of employment, etc. Reasons for losing membership in the Law Society could include appointment to the bench, disbarment, non-payment of fees, etc.

Table 10 shows the attrition rates of women and men who were called to the Bar between 1936 and 1990, but were no longer active members of the Law Society on May 1,1991 . The attrition rates for women are higher than the attrition rates for men in all call groups for which there were women called to the Bar. In examining call groups from 1961 to 1990, the difference between women and men decreases from earlier to later years of call. The greatest difference is for those called between 1961 and 1965; the attrition rate for women is $94 \%$, but only $49 \%$ for men. The next largest difference is for those called between $1966-1970$, where the attrition rate for women is $75 \%$, but only $38 \%$ for men. The smallest difference is for those called between 1986 and 1990, where the attrition rate is $27 \%$ for women and $25 \%$ for men. The total attrition rates for all women and men called between 1936 and 1990 are very similar, 35\% for women and 36\% for men.

In terms of absolute numbers, there were more men than women who were called between 1936-1990 and who were no longer active members in May, 1991. During that time period 2139 men, but only 527 women, became inactive or left the Law Society. In other words, only $20 \%$ of those who were no longer active members were women.

Table 11 shows a more detailed year-by-year breakdown of the attrition rates, as of May, 1991, for women and men called between 1976 and 1990. The attrition rates for women are higher than those for men for eleven of the years of call, lower than those for men for two of the years of call, and the same for two of the years of call. The overall attrition rate for the period 1976-1990 is higher for women (33\%) than for men (28\%). Again, in terms of absolute numbers, there were a greater number of men (1012) than women (443) who were no longer active members as of May, 1991; only $30 \%$ of those who were no longer members were women. Women are leaving their active status in slightly greater proportion than men, however men are leaving their active status in greater numbers than women. 


\section{A SURVEY OF NON-PRACTISING MEMBERS OF THE LAW SOCIETY OF ALBERTA}

A five page questionnaire ${ }^{34}$ (see Appendix A), along with a covering letter from Peter Freeman, Q.C., the Secretary of the Law Society, was sent to all members of the Law Society of Alberta who had become non-practising members between 1987 and 1991, and who resided in Alberta in November of 1991. The questionnaires were mailed out on November 19, 1991 and the last questionnaire used in this paper was received back on March 25, 1992.

\section{A. CHARACTERISTICS OF RESPONDENTS}

\section{Gender and Year of Call}

Table 12 shows the number of non-practising members who were mailed questionnaires, and the number of respondents by gender and year of call in Alberta. The 79 women and 92 men who responded to the survey represented a response from $54 \%$ of both the women and the men; $46.2 \%$ of the respondents were women, and $53.8 \%$ of the respondents were men.

Thirty-nine percent of the men who responded to the questionnaire were called before 1978 , whereas only one woman ( $1 \%$ of the women who responded) was called before 1978. In order to deal with the substantial difference in years of call between the women and men, the analysis which follows has been divided into three sets of respondents: 1) women who were called between 1978 and $1991(\mathrm{~N}=77$; the response rate for this group was 56\%); 2) men who were called between 1978 and 1991 ( $\mathrm{N}=56$; the response rate for this group was 56\%); and 3) men who were called before $1978(\mathrm{~N}=36$; the response rate for this group was 52\%). For the sake of expediency, the first group of men will be referred to as the $78+$ men and the second group as the pre- 78 men. The median ${ }^{35}$ year of call was 1987 for the women, 1988 for the $78+$ men, and 1959 for the pre-78 men.

The women respondents had practised law in all jurisdictions for a median of three years, the $78+$ men for a median of two years, and the pre- 78 men for a median of 27

Members of Alberta's Committee On Gender and Inequality in the Legal Profession reviewed a questionnaire which was developed by the author in collaboration with members of the Law Society of British Columbia's Subcommittee on Women in the Legal Profession. For a similar survey of former members of the Law Society of British Columbia, see "Resistance by the Club', supra note 21 at 87-92 for the questionnaire used in the survey of former members of the Law Society of British Columbia. While many of the questions for this survey are the same as those used in British Columbia, some have been changed and others have been added or deleted, in order to make the questions relevant to inactive members in Alberta, and to the interests of the Alberta Committee. Some of the questions are the same as the ones used in a survey of the active members of the Law Society of Alberta. See "Gender Bias", supra note 13 at 803-808 for the questionnaire used in the survey of active members of the Law Society of Alberta.

The median is the point which divides the number of respondents into two halves, with one-half of the respondents above the median and one-half below it. It is a better summary figure than the mean (i.e. numerical average) when the distribution of responses is skewed. 
years. None of the pre- 78 men and only $15.6 \%$ of the women, as compared to $28.6 \%$ of the $78+$ men, had not practised law. For the most part, the women are comparable to the $78+$ men in terms of years of call, while the pre- 78 men are not comparable to either the women or the $78+$ men.

\section{Age}

The median age was 34 years for the women, 33 years for the $78+$ men, and 60 years for the pre- 78 men. The women ranged in age from 26 to 48 , the $78+$ men from 25 to 63 , and the pre- 78 men from 40 to 83 years. The women and the $78+$ men were very similar in terms of median age, as the 63 year old man was the only man in the group of $78+$ men who was more than 48 years old.

\section{Marital Status and Employment Status of Spouse}

In terms of marital status, $67.5 \%$ of the women respondents, $53.6 \%$ of the $78+$ men, and $86.1 \%$ of the pre-78 men were living in a married or equivalent relationship. Of all those who had spouses, $90.2 \%$ of the women, $90.0 \%$ of the $78+$ men, and only $25.8 \%$ of the men had spouses who were employed.

\section{Children}

Only $28.6 \%$ of the $78+$ men, as compared to $50.6 \%$ of the women and $75.0 \%$ of the pre-78 men in this survey had children. Among these respondents, the women had an average of 2.2 children, the $78+$ men had an average of 2.3 children, and the pre- 78 men had an average of 3.3 children.

\section{Visible Minorities}

Two women (2.6\% of the women), five of the $78+$ men $(8.9 \%)$, and none of the pre-78 men identified themselves as members of a visible minority by virtue of their colour or race.

\section{Respondents With Persistent Disabilities}

Two women (2.6\% of the women), two of the $78+$ men (3.6\%), and two of the pre-78 men $(5.6 \%)$ considered themselves disadvantaged for the purposes of employment by reason of a persistent disability.

\section{B. LEAVING THE PRACTICE OF LAW: WHERE ARE THEY NOW?}

\section{Type of Employment}

Question 1 asked the respondents how they were primarily employed. Table 13 shows that $22.1 \%$ of the women, $33.9 \%$ of the $78+$ men, and only $5.6 \%$ of the pre-78 men were unemployed. Only one of the $78+$ men $(1.8 \%)$, but 17 of the women $(22.1 \%)$, were homemakers. Two additional women were homemakers and working in legal education. 
None of the women and one of $78+$ men were retired, as compared to $52.8 \%$ of the pre78 men. Eleven women $(14.3 \%)$ and five men $(5.4 \%$ of the $78+$ men and $5.6 \%$ of the pre$78 \mathrm{men})$ were involved in legal education. Eight women $(10.4 \%)$ and 15 men $(17.9 \%$ of the $78+$ men and $13.9 \%$ of the pre-78 men) were self-employed, and seven women $(9.1 \%)$ and four $78+$ men $(7.1 \%)$ worked for government.

Of those respondents who were working, the women were much more likely than men to be in positions in which their work was very related to their legal training (50.0\% of the women, as compared to only $29.0 \%$ of the $78+$ men, and $16.7 \%$ of the pre- 78 men). In addition, $34.1 \%$ of the women, $45.2 \%$ of the $78+$ men, and $38.9 \%$ of the pre- 78 men saw their work as somewhat related to their legal training.

Among respondents who were working, $64.4 \%$ of the women, $81.3 \%$ of the $78+$ men, and $55.6 \%$ of the pre- 78 men were working fulltime; $31.1 \%$ of the women, $12.5 \%$ of the $78+$ men, and $27.8 \%$ of the pre- 78 men were working part-time and not seeking fulltime work; $4.4 \%$ of the women $6.3 \%$ of the $78+$ men, and $16.7 \%$ of the pre-78 men were working part-time and seeking fulltime employment. In 1990, the Economic Council of Canada found that "the overwhelming majority" of involuntary part-time jobs were held by individuals who were either young or female or both. ${ }^{36}$ Interestingly, the largest proportion of respondents in this study who were working part-time and looking for fulltime work were the more senior men.

Leaving the practice of law resulted in an increase of income for $15.6 \%$ of the women, $17.9 \%$ of the $78+$ men, and $13.9 \%$ of the pre-78 men. Just under half of the women (49.4\%) and $78+$ men (46.4\%) experienced a decrease in their income, as did $55.6 \%$ of the pre-78 men.

\section{Looking for a Position in the Practice of Law}

Question 6 asked respondents how long in total they had spent not practising law and looking for a position in practice, since their call in Alberta. More than one-half of the women $(53.2 \%), 46.4 \%$ of the $78+$ men, and $16.7 \%$ of the pre-78 men had spent some time looking for a position. However, only $27.3 \%$ of the women, $21.4 \%$ of the $78+$ men, and $13.9 \%$ of the pre-78 men had spent a year or more looking for a position in law.

There were 32 women ( $41.6 \%$ of the women), $2678+$ men ( $46.4 \%$ ), and only five pre78 men (13.9\%) who would have preferred to be practising law at the time of the survey. Of those who did not prefer to be practising law, two women were on parental leave, one woman said "no, not in the situation I was in," one woman had health problems, and two women wrote:

- First time I was let go I fully intended to find another job practising law. However, I had articled and practised in a large firm in Calgary and I had a terrible experience there. I sought employment in smaller 
firms for about 2 years and could not find anything. Consequently, $I$ have decided to cut my losses; forget about practising law; and go on with my life.

- I would prefer to be practising law but not under the conditions which exist in the profession at this time.

Twenty-two of the women (28.6\%), 21 of the $78+$ men $(37.5 \%)$, and three of the pre78 men $(8.3 \%)$ were looking for positions in the practice of law at the time of the survey. All of these respondents, with the exception of one man in the pre-78 group, indicated they were encountering problems in their search. Six men and two women commented on the lack of work and the economic climate. Two women found that they were overly qualified because they had specialized, and another wrote, "my age and length of practice in a new city would hamper my abilities." One woman had problems finding a part-time position or a position with flexible time. Other women wrote:

-... I have spent 2 years unsuccessfully seeking employment. I had trouble finding a position because of the poor quality of articles. All I did was research and associates need to be able to do more than this. Also, my principal disliked it when I worked for other lawyers so my research was all in one area.

- I am not now working because I am due to have another baby ... [I] completed articles [recently] and was not kept on. Have not looked for employment yet (because I want part-time/job share).

- It is difficult to look for a position in the practice of law after one has been on the inactive list for a substantial period of time.

One man wrote that he was "getting offers to work without a base salary, without any of my fees or insurance being paid, and only $40 \%$ commission or by receipts." A second was "thinking about" looking for a position in the practice of law, and a third wrote, "you got to be kidding!" Two men commented on the excessive number of lawyers. Another wrote:

- Main reasons why I am not presently pursuing a position in the practice of law: 1. with my level of practice experience (1 $1 / 2$ years following articles) unlikely I can obtain legal position paying better than what $I$ am presently earning. 2. quasi-government job provides me with more job security than an associate position in a law firm.

\section{Satisfaction With Work in the Legal Profession}

Respondents were asked how satisfied they were (on a scale of $1=$ very satisfied to $7=$ very dissatisfied) with thirteen aspects of their work when they last worked in the legal profession. Table 14 shows a detailed breakdown of the responses by gender. In order to summarize the results, the percentages in the text refer to collapsed categories (1$3=$ satisfied; $4=$ neutral; $5-7=$ dissatisfied). ${ }^{37}$ 
The greatest number of women were dissatisfied with the balance between their work and their personal life (61.3\%). Other areas of work with which women respondents were dissatisfied (in decreasing order) were: hours $(52.6 \%)$, control over work $(52.0 \%)$, opportunity for advancement (49.3\%), job security (45.3\%), money (42.1\%), male colleagues (34.7\%), employment benefits (34.2\%), and administration (30.6\%). More than $30 \%$ of the $78+$ men were dissatisfied with control over work $(60.7 \%)$, job security (53.6\%), opportunity for advancement (44.6\%), balance with personal life (43.6\%), hours (41.1\%), employment benefits (39.3\%), money (37.5\%), and administration (36.4\%). The greatest number of pre-78 men were dissatisfied with hours $(20.6 \%)$, and over $55 \%$ of them were satisfied with all other aspects of their work when they last worked in the legal profession.

The greatest difference between the women and the $78+$ men with reference to aspects of work which satisfied them, was respecting "balance with personal life." Only $26.7 \%$ of the women, as compared to $40.0 \%$ of the men, were satisfied with this balance. With a few other exceptions, the women and $78+$ men were quite similar in their responses. On the other hand, there were major differences between the $78+$ men and the pre-78 men. For example, only $37.5 \%$ of the $78+$ men were satisfied with money as compared to $76.5 \%$ of the pre- 78 men. Only $33.9 \%$ of the $78+$ men were satisfied with the control they had over their work, as compared to $69.7 \%$ of the pre- 78 men. Similarly, only $32.1 \%$ of the $78+$ men were satisfied with job security, as compared to $63.6 \%$ of the pre- 78 men. The women $(61.3 \%)$ and the pre-78 men $(73.5 \%)$ were more likely to be satisfied with the prestige of their work than the $78+$ men $(51.8 \%)$.

\section{Reasons For Leaving the Practice of Law}

Question 11 asked respondents how relevant (on a scale of $1=v e r y$ relevant to $7=$ not at all relevant) each of seventeen factors was in explaining why they were not practising law. They were also asked to specify any other reasons which were relevant to their decision, and to elaborate on any of these influences. Table 15 shows a detailed breakdown of the responses by gender. In order to summarize the results, the percentages in the text refer to collapsed categories: 1-3 (relevant), 4 (neutral) and 5-7 (not relevant). ${ }^{38}$ The percentages of women and men who circled " 7 " (not relevant at all) is also noted in the text.

These factors will be discussed individually, and in the context of comments made by the respondents. The numbers in brackets are the order in which the factors were most frequently identified by each of the three groups as reasons why they are not practising law. Some of the respondents' comments applied to more than one factor, but they are reproduced only once. 


\section{Hours Demanded by Practice}

[\#1 for women, \#5 for $78+$ men, \#4/5 for pre-78 men] Hours were identified as a reason for not practising law by $73 \%$ of the women, $40 \%$ of the $78+$ men, and $37 \%$ of the pre-78 men who responded to this question. Two women commented:

- I am presently working where I am a member of a bargaining unit which has negotiated "hours of work" for employees. We work 35 hours/week and any work in excess of that is overtime.

The major attraction of this is not just working less but that having defined working hours helps "switch off" work - making it easer to relax and not think of work.

The hours of work is what attracted me to the job. The switch of jobs was not motivated by a desire to leave law but to work in a better and healthier environment.

- The hours demanded by practice leave little time or energy for outside activities including community service and charitable activities. As the desire to participate in these activities was a major factor in my decision to become a lawyer it seemed rather self-defeating to continue in practise.

Hours were not at all relevant for $16 \%$ of the women, $31 \%$ of the $78+$ men, and $44 \%$ of the pre-78 men.

\section{Stressful Nature of Work}

[\#2 for women, \#4 for $78+$ men, \#3 for pre-78 men] The stressful nature of their work was a consideration for $61 \%$ of the women, $43 \%$ of the $78+$ men, and $47 \%$ of the pre- 78 men in leaving the practice of law. It was not relevant at all for $17 \%$ of the women, $33 \%$ of the $78+$ men, and $12 \%$ of the pre-78 men.

\section{Lack of Flexibility in Firm}

[\#3 for women, \#9 for $78+$ men, not relevant for pre-78 men] Lack of flexibility in their firm was a factor for $60 \%$ of the women, $32 \%$ of the $78+$ men, and none of the pre78 men. One woman wrote:

- The fact that I know it will be difficult to attain a position in private practice after time off to have a family has influenced my decision to work towards a teaching job. I see this as something I can work towards whilst at home...

...I completed my articles at a very large Edmonton firm and was asked to stay on. I was pregnant with my second child and inquired about a part-time arrangement. I was offered a part-time research job on the understanding that my years of doing this would not give me any seniority. That is, all my contemporaries would move ahead but I would be deemed a first year associate as and when I began fulltime work again. To my mind there was just no point in this arrangement and I was better employed with my children and taking my chances in the future.

I would add that I also had three years experience in practice in [another country] so that this proposed arrangement just seemed like a backward step to me.

Lack of flexibility in their firm was not relevant at all for $22 \%$ of the women, $34 \%$ of the $78+$ men, and $58 \%$ of the pre- 78 men. 


\section{Felt Burnt Out}

[\#4 fòr women, \#11/12/13 for 78+ men, \#2 for pre-78 men] Forty-three percent of the women, $25 \%$ of the $78+$ men, and $63 \%$ of the pre- 78 men indicated that they "felt burnt out" by the practice of law. Forty percent of the women, $50 \%$ of the $78+$ men, and only $6 \%$ of the pre-78 men said this was not at all relevant. Interestingly, burn out was a factor for more of the pre-78 men than the women or the $78+$ men. Men, as a group, appear to be burning out at a slower pace than women.

\section{Child Care Commitments}

[\#5 for women, \#17 for $78+$ men, not relevant for pre-78 men] Child care commitments either pushed or pulled $42 \%$ of the women respondents, but only $8 \%$ of the $78+$ men and none of the pre- 78 men from the practice of law. Child care commitments were not at all relevant for $57 \%$ of the women, $90 \%$ of the $78+$ men, and $86 \%$ of the pre-78 men. Considering the fact that only $50.6 \%$ of the women respondents had children, it appears as though there are few women with children who leave the practice of law without child care being one of the factors which influence this decision. Women wrote:

- I was practising with a large law firm and very much enjoyed the work itself, however, the nature of practice hours and expectations within the firm and with large law firms throughout this province made my situation stressful and ultimately led me to quit practice. I started practice with a child and constantly found childcare a problem because I was working 12-14 hour days. My husband ... faced similar hours. No nanny or daycarc centre would tolerate such hours, so I ended up using both in order to give my nanny time off. But even with that arrangement I found pressure to stay later in the evenings, not go home for dinner and work more than 1 day per weekend. Additionally, client promotions which went on during evenings meant more time away from my family.

When I was expecting my second child I decided it was too much stress to even think of returning to full-time practice after the child was born, so I decided to remain home full-time. This has allowed me not only to care for my second child but also participate in my eldest child's school activities which I consistently missed while practising. If part-time practice were possible, I would like to practise law but I have been laughed at when I mention it. I was practising litigation and have been told repeatedly that part-time is impossible. And yet I knew through my practice a few part-time lawyers employed by the federal and provincial governments. Unfortunately, their positions were in Edmonton, while I am not...

-...In any event, the practice of law and my four children are absolutely incompatible. I do not want my children speaking with a Filipino accent as a consequence of $\mathbf{7 0}$ hour work weeks. I do not want to be emotionally absent from our children. I am very fortunate in that I have a professional husband who supports me in my ideals and an employer who, when I resigned, insisted on keeping my position open for me for three years while I stayed home with the baby...

\section{Wanted to Use Different Skills}

[\#6 for women, \#1 for 78+ men, \#1 for pre-78 men] Thirty-eight percent of the women, $47 \%$ of the $78+$ men, and $75 \%$ of the pre- 78 men said that they wanted to use different skills, while $44 \%$ percent of the women, $22 \%$ of the $78+$ men, and $19 \%$ of the pre- 78 men said this was not at all relevant. 


\section{Adversarial Nature of Work}

[\#7 for women, \#2 for $78+$ men, \#7 for pre-78 men] Thirty-six percent of women, $46 \%$ of $78+$ men, and $33 \%$ of the pre-78 men identified the adversarial nature of work as a reason for not practising law. This was not at all relevant for $35 \%$ of the women, $25 \%$ of the $78+$ men, and $27 \%$ of the pre- 78 men. These findings are interesting in light of other studies which suggest that women are reluctant adversaries ${ }^{39}$ and are more likely to practice law from a conciliatory rather than an adversarial perspective. ${ }^{40}$

\section{Law Society Fees/Insurance}

[\#8 for women, \#10 for $78+$ men, \#6 for pre-78 men] Law Society fees or insurance were relevant for $33 \%$ of the women, $31 \%$ of the $78+$ men, and $35 \%$ of the pre- 78 men, but not at all relevant for $46 \%$ of the women, $39 \%$ of the $78+$ men, and $12 \%$ of the pre78 men.

\section{Cannot Find a Job}

[\#9 for women, \#3 for $78+$ men, \#12 for pre-78 men] Thirty-one percent of the women, $45 \%$ of the $78+$ men, and $15 \%$ of the pre- 78 men could not find a job. This factor was not at all relevant for $47 \%$ of the women, $45 \%$ of the $78+$ men, and $77 \%$ of the pre- 78 men. One man wrote:

- I have been offered jobs in private practice but I say I cannot find a job, I mean I cannot find a job that I would want to take.]

Better Position Outside Law

[\#10/11 for women, \#6 for $78+$ men, \#4/5 for pre-78 men] A better position outside law drew $30 \%$ of the women, $37 \%$ of the $78+$ men, and $37 \%$ of the pre- 78 men from the practice of law. A better position outside law was not at all a relevant consideration for $46 \%$ of the women, $45 \%$ of the $78+$ men, and $50 \%$ of the pre- 78 men.

\section{Loss of Employment}

[\#10/11 for women, \#7 for 78+ men, \#8 for pre-78 men] Loss of employment was a factor for $30 \%$ of the women, $36 \%$ of the $78+$ men, and $25 \%$ of the pre- 78 men in leaving

39 J.C. Foster, "Antigones in the Bar: Women Lawyers as Reluctant Adversaries" (1986) 10:3 Legal Studies Forum 287.

40 C. Hotel and J. Brockman, "The Conciliatory-Adversarial Continuum in Family Law Practice" (1994) 12:1 Can. J. Fam. L. (in press). R. Jack \& D. Crowley Jack, Moral Vision and Professional Decisions: The Changing Values of Women and Men Lawyers (Cambridge: Cambridge University Press, 1989) found that while women and men fell along a continuum of "care" to "rights," women were more likely to fall at the "care" end of the continuum, and men at the "rights" end of the continuum. 
the practice of law. It was not at all relevant for $57 \%$ of the women, $50 \%$ of the $78+$ men, and $56 \%$ of the pre- 78 men.

\section{Low Pay/Income}

[\#12 for women, \#8 for $78+$ men, \#13/14 for pre-78 men] Low pay was a consideration for $23 \%$ of the women respondents, $35 \%$ of the $78+$ men, and $14 \%$ of the pre- 78 men. It was not relevant at all for $50 \%$ of the women, $39 \%$ of the $78+$ men, and $64 \%$ of the pre-78 men.

\section{Exposure to Liability}

[\#13 for women, \#11/13 for 78+ men, \#10/11 for pre-78 men] Twenty-one percent of the women, $25 \%$ of the $78+$ men, and $21 \%$ of the pre- 78 men identified exposure to liability as a reason for not practising law. This was not at all relevant for $54 \%$ of the women, $44 \%$ of the $78+$ men, and $29 \%$ of the pre- 78 men.

\section{Bored}

[\#14 for women, \#11/12/13 for 78+ men, \#9 for pre-78 men] Twenty percent of the women, $25 \%$ of the $78+$ men, and $23 \%$ of the pre- 78 men said they were "bored" with the practice of law. One woman circled "bored" and wrote, "yes!!" Boredom was not at all relevant for $54 \%$ of the women, $37 \%$ of the $78+$ men, and $46 \%$ of the pre- 78 men.

\section{Spouse's Career}

[ \#15 for women, \#16 for 78+ men, not relevant for pre-78 men] A spouse's career was a factor in leaving practice for $19 \%$ of the women and $10 \%$ of the $78+$ men, but for none of the pre-78 men. It was not at all relevant for $70 \%$ of the women, $82 \%$ of the $78+$ men, and $86 \%$ of the pre- 78 men.

\section{Lack of Opportunity for Advancement}

[\#16 for women, \#14 for 78+ men, \#13/14 for pre-78 men] Lack of opportunity for advancement was a consideration for $17 \%$ of the women, $22 \%$ of the $78+$ men, and $14 \%$ of the pre-78 men. It was not at all relevant for $53 \%$ of the women, $44 \%$ of the $78+$ men, and $71 \%$ of the pre- 78 men.

\section{Higher Income Outside Law}

[\#17 for women, \#15 for $78+$ men, \#10/11 for pre-78 men] Thirteen percent of the women, $18 \%$ of the $78+$ men, and $21 \%$ of the pre- 78 men were attracted to higher incomes outside of law. This was not at all relevant for $71 \%$ of the women, $57 \%$ of the $78+$ men, and $57 \%$ of the pre- 78 men. 
Other

Some of the respondents identified additional reasons for not practising law. Women added: "poor working environment," "illness," "greater satisfaction," "[being] a plaintiff in a difficult law suit which caused emotional distress," "tired of crusading to improve public image of the profession," "no community legal clinics in Alberta," "sexual discrimination," "wanted job satisfaction," "better outside i.e. more suitable given all my contingencies," and "the fact that I do not perceive women to be welcome in the legal profession." Another woman commented:

- I left private practice because, while I enjoy working in law, I very much disliked the business of running a practice.

In general, I found it disturbing that (more) lawyers are concerned with "running a business" rather than providing an essential service to the public. I believe that this attitude has made legal services inaccessible to many people (and has made accessing legal services very intimidating to people!). Less marble and more services!

One of the men who was retired from the practice of law would have preferred a gradual retirement process, and his comments are reproduced under the section "Suggestions for Reform." Another retired man wrote,

- Decided to relax and enjoy life. Saw too many of my friends dying too young without having enjoyed

"the fruits of their labours."

Two men left the practice of law because of illness, and a third because of a head injury. Other reasons for men leaving the practice of law included: "job security better in present position," "cut throat lack of collegiality," "moved to Calgary and the legal opportunities here are negligible," "lawyers," "wanted holidays," "concern for change in legal profession from respected profession to less-principled business," "different career desired," "difficulty in amassing grubstake to begin own practice," "wanted more leisure time," "elected to office," and "[became] a full-time student." One man wrote that his "career objective was to teach law," and another said:

- As business partners most lawyers are "jerks." Lawyers have to argue about everything. They tend not to co-operate with each other. They tend to build empires. They don't share work unless it's a "dog file."

\section{Intention to Practise Law}

Respondents were also asked if they had intended to practise law when they entered law school. Most of the women $(72.7 \%)$ and the men $(73.2 \%$ of the $78+$ men and $88.9 \%$ of the pre-78) had intended to practise law. Almost all of the other respondents were "not sure."

Doing it Over Again

Question 33 asked respondents if they would become lawyers if they could "do it over again." Forty-four percent of the women, $50 \%$ of the $78+$ men, and $69.4 \%$ of the pre-78 
men said they would; $41.6 \%$ of the women, $44.6 \%$ of the $78+$ men, and $30.6 \%$ of the pre78 men said they would not. Comments from women included: "too soon to say," "would obtain LL.B., not certain that I would have entered private practice," "yes, but a dentist would be ideal! Regular hours and no work to take home," "no but I would still obtain an LL.B.," and:

- Yes, in the sense that I would obtain an LL.B., and, maybe article. But I do not regret not practising in the usual way. If I did I would go into practice.

\begin{abstract}
- In the survey you asked whether or not I would do it all over again. I wasn't sure at the time and I have thought about the question in a lot of depth. I now know that the answer is "no." I think that, on consideration, medicine would have been a lot better career. It is much more adaptable to the blending of a career and a family. I think there is far less of a tendency to be discounted if you are a female doctor in that there is little of an adversarial element in the practise of medicine. My limited experience with the practise of law shows me that you are always on edge. You carry your cases with you everywhere. It appears to me that if you don't get personally involved, you aren't doing your job. That burns you out and there is nothing left for your family. The addiction rate in law bears this out. I think there is a real tendency among lawyers to think as if alcohol and drugs are the only addictions which harm the practitioner. Nothing could be further from the truth. Other addictions such as the work itself, food, sexual addiction and perhaps gambling are harming the profession in a very real way.
\end{abstract}

Comments from men included: "not sure" "definitely not - never," "no, but have no real strong talents in any direction," and (from a man called to the Bar for less than five years) "never, ever, ever in a billion years."

\title{
C. GENDER BIAS IN THE LEGAL PROFESSION
}

Questions 15 and 16 asked the respondents about their perception of the existence of gender bias or discrimination in the legal profession in Alberta. Question 17 asked respondents who thought gender bias or discrimination existed to identify the nature of that bias or discrimination. Respondents were given seventeen forms of bias to consider, and asked to identify any additional type of bias they perceived.

Table 16 shows that an overwhelming majority of the respondents in this survey ( $97.4 \%$ of the women, $83.9 \%$ of the $78+$ men, and $75.0 \%$ of the pre- 78 men) were of the view that there was some bias or discrimination against women in the legal profession. The women were more likely to think it was "widespread" (74.0\%) than the 78+ men (39.3\%) or the pre- 78 men $(25.0 \%)$, and the men $(44.6 \%$ of the $78+$ men and $50.0 \%$ of the pre-78 men) were more likely than the women (23.4\%) to think that gender bias against women existed, but was not widespread. One of the women who did not respond to the question wrote, "heard about it - not experienced any." Another woman wrote, "In some areas and firms it is extremely blatant. In other areas and firms it is more subtle."

With regard to gender bias or discrimination against men in the legal profession, $76.6 \%$ of the women, $46.4 \%$ of the $78+$ men, and $55.6 \%$ of the pre- 78 men were of the opinion that there was none. Most of the respondents who thought it existed, thought it was not widespread. One woman respondent wrote that there was a "widespread preference 
favouring men," while another wrote that gender bias "particularly affects men who take active roles in childcare and/or support professional partners/spouses." Two men who indicated that gender bias exists against men but was not widespread wrote "feminism has a dark side" and "it is very difficult to pinpoint."

\section{The Nature of Bias or Discrimination Against Women}

Table 17 sets out the areas in which the respondents thought that women and men faced gender bias or discrimination in the legal profession.

\section{Career advancement and attaining partnership}

"Career advancement" and "attaining partnership" were most frequently mentioned by the women and both groups of men as an area in which women are discriminated against. "Career advancement" was identified by $81.8 \%$ of the women, $60.7 \%$ of the $78+$ men, and $38.9 \%$ of the pre- 78 men. "Attaining partnership" was identified by $75.3 \%$ of the women, $51.8 \%$ of the $78+$ men, and $38.9 \%$ of the pre- 78 men as being an area that women are discriminated against. One woman put two exclamation marks beside this question, and a second wrote:

\footnotetext{
- In my experience, females were slotted into "family law" whether this was the preferred area of practice or not. The billing targets to actual wages in ratio were less than $1 / 3$. It was more like slavery than a career with the partners coasting on the sweat of others. Don't get me wrong, I'm willing to start at the bottom and work my way to the top - but there was no top. The firm I worked in did not after 7 years make a female associate a partner. She met her billings and exceeded the target for the past [number] years and there was still no intention of making her a partner. I could see myself being treated in the same manner. No advancement and little recognition of a job well done were my experiences. The practice of law is difficult enough without any support from peers...
}

... All around it was a bad experience. The firm has no female associates at this point in time and personally, they shouldn't be allowed to have any as they mistreat them anyways.

\section{Lack of accommodation for family commitments}

Including those respondents who indicated that a particular bias exists against both women and men, the third most prevalent category of discrimination against women, according to the women (72.7\%), was in the "lack of accommodation for family commitments." Only $39.3 \%$ of the $78+$ men and $30.6 \%$ of the pre- 78 men agreed with the women. Comments (the first three by women and the fourth by a man) included:

- Of course there is discrimination against women in the legal profession. Discrimination against women is endemic, and since the legal profession is amongst the most conservative (read, in this context, backward) sectors of society, it must be and indeed is found there. I wasn't really in the legal profession for long and I don't go looking for discrimination but I certainly saw it around me. The most obvious aspects of it were in the assumptions that governed the firm I articled with. The single most discriminatory assumption was that the firm should constitute one's primary commitment, meaning that as many waking hours as possible were to be spent there. For women this just won't do: in fact for lots of men it won't either, but that is another story. For anyone who takes family seriously, such an 
assumption is just impossible to live with. I didn't want to live with it, and had something else to do with myself, but for those who try to mould themselves to it the results can be catastrophic.

- Timing of meetings, briefings, etc. [with reference to lack of accommodation].

- Inflexible re alternative work arrangements, expecting all people to fit within very narrow parameters e.g. appearance, clothing, etc.

- I think that the legal profession is overly materialistic (like most of our culture) and does not value the family enough. Money and prestige is more important than relationships.

\section{Access to clients}

"Access to clients" was reported by $59.7 \%$ of the women, $23.2 \%$ of the $78+$ men, and $16.7 \%$ of the pre-78 men as a sphere in which women are discriminated against.

\section{Assignment of files}

According to $58.4 \%$ of the women, $25.0 \%$ of the $78+$ men, and $13.9 \%$ of the pre- 78 men, women lawyers are discriminated against in the "assignment of files."

\section{Hiring}

Fifty-seven percent of the women, $33.9 \%$ of the $78+$ men, and $27.8 \%$ of the pre-78 men reported "hiring" as a field in which women are discriminated against. A woman commented:

-...Another obvious manifestation of discrimination was an example of the old maxim that women have to be twice as good to get to the same place as comparable men. When I articled, there were four people from my graduating law class articling with the same firm - two men and two women. The two women were the top and the next to the top (or nearly) in their class. The men were pretty far down the ladder. Don't get me wrong: marks in law school shouldn't be determinative of one's career, but the contrast in the case I cite was glaring enough to be largely explicable on the following basis: the only women the firm were going to take a chance on were the academically best. Men could get by with weaker qualifications. And I am not at all sure that this result was consciously imposed...

\section{A man wrote:}

- When I was looking for articles, and when I almost took an offer to become an associate lawyer, a great many practitioners told me they would prefer to hire a man over a woman.

\section{Appropriate weight not given to opinions}

"Other lawyers not giving appropriate weight to opinions" was identified by $55.8 \%$ of the women, $28.6 \%$ of the $78+$ men, and by $33.3 \%$ of the pre- 78 men as an area in which women are discriminated against. 
Remuneration

Women lawyers are discriminated against in "remuneration" according to $51.9 \%$ of the women, $26.8 \%$ of the $78+$ men, and $27.8 \%$ of the pre- 78 men. Women wrote:

- I do not think there is any direct attempt to pay women less than their male counterparts, however, the bias which prevents women from access to many clients and the bias which affects the assignment of work indirectly affects women's remuneration. Women tend to get edged into practice areas which produce a lower rate of return.

- I should add that the male student hired after me received more money as a student and as a first year associate than I did.

Unwanted teasing, jokes or comments of a sexual nature

Almost one half of the women (46.8\%), $37.5 \%$ of the $78+$ men, and $22.2 \%$ of the pre78 men identified unwanted teasing, jokes or comments of a sexual nature as an area in which women are discriminated against. One woman put two exclamation marks beside her response, and a second wrote, "this occurs, but does not bother me personally."

Access to managerial positions

"Access to managerial positions" was seen as an area in which women are discriminated against by $44.2 \%$ of the women, $25.0 \%$ of the $78+$ men, and $33.3 \%$ of the pre-78 men.

Judicial attitudes

"Judicial attitudes" were identified by $44.2 \%$ of the women, $23.2 \%$ of the $78+$ men, and $22.2 \%$ of the pre- 78 men as an area in which women are discriminated against in the legal profession. One woman thought that these attitudes were "not bad though."

Nature of office and promotional functions

According to $40.3 \%$ of the women, $19.6 \%$ of the $78+$ men, and $16.7 \%$ of the pre-78 men the nature of office/firm functions is a realm in which women are discriminated against; $37.7 \%$ of the women, $14.3 \%$ of the $78+$ men, and $13.9 \%$ of the pre-78 men identified promotional functions as such. With regard to office functions, one man wrote that, "some large firms have gained notoriety in this area."

Unwanted sexual advances

Unwanted sexual advances were reported by $29.9 \%$ of the women, $23.2 \%$ of the $78+$ men, and $19.4 \%$ of the pre- 78 men as a form of discrimination against women in the legal profession. One woman described the effect of such behaviour on her work: 
-...The overtime could not be done at the office as certain male partners over indulged in alcohol and I found myself physically accosted one evening. Consequently, I was not recognized as "hard working" as all "extra" work was done at home in the evenings and on weekends...

Setting hourly rate

"Setting hourly rates" was identified by $23.4 \%$ of the women, $8.9 \%$ of the $78+$ men, and $8.3 \%$ of the pre- 78 men as an area in which women are discriminated against in the legal profession.

\section{Judicial appointments}

Thirteen percent of the women, $16.1 \%$ of the $78+$ men, and $8.3 \%$ of the pre- 78 men, were of the view that women are discriminated against in the legal profession when it comes to judicial appointments.

Opportunity to appear in court

"Opportunity to appear in court" was identified as an area in which women are discriminated against by $11.7 \%$ of the women, $7.1 \%$ of the $78+$ men, and $5.6 \%$ of the pre78 men.

\section{Other forms of discrimination against women}

Other forms of discrimination described by women included: "informal socializing within firms," and "nature of legal education." A man wrote:

- I believe there are some male lawyers who do not treat female lawyers with the same respect they treat other male lawyers simply because they are female. I also think that there are instances where female lawyers treat male lawyers in the same way.

These results, especially the difference between the $78+$ men and the pre- 78 men, might provide some insights into the "inroads" which women are making in the legal profession. The biggest difference between these two groups of men is that $60.7 \%$ of the $78+$ men, and only $38.9 \%$ of the pre- 78 men, recognize "career advancement" as an area in which women are discriminated against. ${ }^{41}$ The second largest difference is that $21.5 \%$ of the $78+$ men, and only $2.8 \%$ of the pre- 78 men, identified "lack of accommodation for family commitment" as an area in which men were discriminated against. The third largest difference is that $37.5 \%$ of the $78+$ men, and only $22.2 \%$ of the pre-78 men, see "unwanted sexual teasing and jokes" as a form of discrimination against women in the legal profession. These three areas have been the target of much study and resulting policies in law firms and law societies across Canada since the late $1980 \mathrm{~s}^{42}$ It may be men identified access to managerial positions as an area in which women were discriminated against. 
as suggested by Mary Jane Mossman, ${ }^{43}$ that women who are having problems with the lack of accommodation for family commitments might find allies among the younger men of the profession.

\section{The Nature of Bias or Discrimination Against Men}

As is shown in Table $16,76.6 \%$ of the women, $46.4 \%$ of the $78+$ men and $55.6 \%$ of the pre-78 men thought there was no bias or discrimination against men in the legal profession. Most of those who thought there was bias thought that it was not widespread.

The most frequently identified area in which men are discriminated against, according to the women $(14.3 \%)$ and the $78+$ men $(21.5 \%)$, was "lack of accommodation for family commitment." ${ }^{14}$ One woman commented that "many males suffer if they support a working spouse or take childcare responsibilities seriously."

"Judicial appointments" was an area most frequently mentioned by the pre-78 men (5.6\% identified this as an area in which men were discriminated against and $5.6 \%$ identified this as an area in which both women and men were discriminated against). Less than $5 \%$ of the pre-78 men identified other areas as areas in which men were discriminated against. The next most frequently identified areas by the $78+$ men were "hiring" and "judicial appointments."

Comments by men on the nature of bias against men included: "[bias against men in] family practice," "[judicial appointments] Definitely! Unqualified women appointed to the bench over more qualified men," and "[bias against men] in trying to get legal positions with governmental agencies."

\section{PERSONAL EXPERIENCE WITH BIAS OR DISCRIMINATION}

Question 22 asked respondents whether they had experienced discrimination while seeking employment as a lawyer or while employed as a lawyer, on the basis of sex, colour or race, disability, age, marital status, sexual orientation, parental status, or "other."

\section{Discrimination on the Basis of Sex}

Almost three-quarters of the women (72.7\%) had experienced discrimination by lawyers on the basis of sex, and $40.3 \%$ had experienced such discrimination by clients. None of the pre-78 men and $12.5 \%$ of the $78+$ men reported experiencing discrimination by lawyers on the basis of sex; $3.6 \%$ of the $78+$ men and $5.6 \%$ of the pre-78 men reported discrimination by clients. A woman commented:

M.J. Mossman, "Women and Men in the Legal Profession: New Directions" Gender Equality $-A$ Challenge for the Legal Profession (Ottawa: Canadian Bar Association, 1992) [hereinafter "New Directions"].

4 This includes those respondents who indicated that bias or discrimination exists against both women and men. Only $2.8 \%$ of the pre- 78 men identified this as an area of discrimination against men. 
- In my experience often clients would call for legal advice and upon answering the phone they would tell me they wished to speak to a lawyer not a secretary. This would happen, on average, at least twice a week. The performance of my work for people like this was always met with a type of surprise, that I actually knew what I was doing. Bias "by other lawyers" was not from those outside of my firm but, rather, from my colleagues. My sex determined the slant of my practice, which after six months at the bar went from a general smattering to $95 \%$ matrimonial work, basically divorce work. There was only one other male matrimonial lawyer in the firm and the bulk of his practice was foreclosures. The matrimonial work accorded him was the biggies where there was a lot of property to split. It was like being chosen as the guy who takes out the garbage. My forays into commercial law were met with resistance by fellow lawyers and such matters were relegated away from me or I was not given those "cold calls" any longer once the receptionist was told who got what.

The issue of sexism in the legal profession will receive more consideration by the Canadian Bar Association Task Force on Gender Equality, chaired by the Honourable Bertha Wilson, when the Committee reports to its members in August of 1993. ${ }^{45}$

\section{Discrimination on the Basis of Colour or Race}

One woman, two $78+$ men, and one pre-78 man had experienced discrimination by lawyers on the basis of colour or race; and one woman, three 78+ men, and none of the pre-78 men had experienced such discrimination by clients. Law societies and law committees across Canada have started to examine the issue of racism and underrepresentation of Aboriginal people and ethnic and visible minorities in law schools and the profession. ${ }^{46}$

\section{Discrimination on the Basis of Disability}

One woman, one $78+$ man, and none of the pre-78 men reported experiencing discrimination by lawyers on the basis of disability, and none of the women, two of the $78+$ men and one of the pre-78 men reported experiencing discrimination by clients on the basis of disability. Little is known about the numbers of women and men in law

The Report focuses on "the twin themes of barriers to entry and barriers to equality within the profession. [lt focuses] on issues of representation and employment opportunities, on fairness in career development and advancement, on the duty to accommodate family responsibilities and on the elimination of sexual harassment and sexual discrimination in each sector of the profession." Letter by Bertha Wilson to the author updating those who participated in the consultation process, dated July 30, 1993.

For example, see G. Ferguson, Report to the Planning Committee on Multicultural Issues in the Legal Profession (Vancouver: Law Society of British Columbia, April 1992) and B.J. Wallace, "Racial Equality: Another Pressing Issues" (March-April 1993) Benchers' Bulletin 2 and "Racial Discrimination the Next Challenge" (October 1992) Benchers' Bulletin 1 for some of the activities by the Law Society of British Columbia. The Nova Scotia Barristers' Society has established a Race Relations Committee. See also Special Advisory Committee to the Canadian Association of Law Teachers, Equality in Legal Education: Sharing a Vision, Creating the Pathways, by Alvi, Tariq, R. Boyko, L. Ma, W. MacLauchlan, T. Monture, Y. Peters and J. St. Lewis (Toronto: The Association, 1991); reprinted in (1992) 17 Queen's L.J. 174-214 and S. Neallani, "Women of Colour in the Legal Profession: Facing the Familiar Barriers of Race and Sex" (1992) 5:1 C.J.W.L. 148. 
schools or in the legal profession who have disabilities, however, it is estimated that 10-15 percent of Canada's population have a physical or mental disability. ${ }^{47}$

\section{Discrimination on the Basis of Age}

Discrimination by lawyers on the basis of age was experienced by $22.1 \%$ of the women, $14.3 \%$ of the $78+$ men, and $5.6 \%$ of the pre- 78 men. Such discrimination by clients was experienced by $23.4 \%$ of the women, $14.3 \%$ of the $78+$ men, and by $11.1 \%$ of the pre-78 men.

\section{Discrimination on the Basis of Marital Status}

Discrimination by lawyers on the basis of marital status was experienced by $16.9 \%$ of the women, $8.9 \%$ of the $78+$ men, and $5.6 \%$ of the pre- 78 men. Such discrimination by clients was reported by $1.3 \%$ of the women and by none of the men.

\section{Discrimination on the Basis of Parental Status}

Discrimination by lawyers on the basis of parental status had been experienced by $14.3 \%$ of the women, $3.6 \%$ of the $78+$ men, and $2.8 \%$ of the pre-78 men. Such discrimination by clients was reported by $1.3 \%$ of the women and by none of the men. One woman wrote:

- I have been asked in several job interviews whether my child is in reliable daycare. I don't think for one second that a man would be asked such a thing.

\section{Discrimination on the Basis of Sexual Orientation}

None of the respondents reported experiencing discrimination on the basis of sexual orientation. It does not follow, however, that such discrimination is not a problem in the legal profession. A number of submissions to the Canadian Bar Association on Gender Equality clearly indicated that discrimination on the basis of sexual orientation is a problem in the legal profession. ${ }^{48}$ The Law Society of British Columbia's Gender Bias Committee outlined some of the extra hurdles faced by gay men and lesbian women in the legal profession. ${ }^{49}$ the Law School" (1991) 36 McGill L.J. 636, who makes 27 specific recommendations about what law schools can do to ensure that disabled persons have equal access to the practice of law and to the services of lawyers. 


\section{Other forms of Bias or Discrimination}

A number of women respondents added the following experiences of discrimination by lawyers: "pregnancy", "weight" (two respondents), "personal appearance", "province of origin", and:

- Being single and being seen as available for reasons other than law (sex?). Hired as a "friend" and more or less secretarial than as a lawyer.

- I am a divorced woman. While seeking employment as a lawyer, I was offered an associate position by a male lawyer in his $60 \mathrm{~s}$. During subsequent negotiations of financial remuneration this lawyer stated that he was not willing to discuss money until I had met his wife and convinced her that it was safe to have me, "a young woman experiencing marital difficulties" working with her husband. He told me that he thought his wife would be jealous. I didn't take the job.

Men indicated that they were discriminated against by lawyers on the basis of "ethnicity," "depression," and "lack of experience." One man commented:

- By old boy network who are always insecure about people who have different opinions from them and are intellectually honest enough to express them.

\section{E. SUGGESTIONS FOR REFORM}

Respondents were asked if the Law Society should take any action to facilitate or encourage members to retain their active status in the Law Society; $40.3 \%$ of the women, $21.4 \%$ of the $78+$ men, and $25.0 \%$ of the pre- 78 men who responded to this question indicated that the Law Society should do something. When asked whether they thought that changes in the legal profession were necessary to better accommodate the needs of people such as themselves, $75.3 \%$ of the women, $42.9 \%$ of the $78+$ men, and $19.4 \%$ of the pre-78 men were of the view that such changes were necessary.

The respondents were also asked to elaborate on what the Law Society should do to encourage members to retain their active membership, and what changes they would like to see in the legal profession. More flexibility with regard to membership status and balance with personal life were most frequently identified as areas in need of change.

\section{Active-Inactive Membership Status}

Suggestions for changes to the membership classification included expanding the present list to active members who are exempt from paying insurance, or creating a new class of active members. Women wrote:

- I would like to retain "active" status but not have the burden of the insurance assurance fees since I do not wish to "practise" law. My present position requires legal training, knowledge and keeping current but I do not practise. 
- It might be helpful to some members if they, while they are inactive, could go on the active list without paying the liability insurance premium. If someone is not practising law (by reason of unemployment or choice), there does not appear to be any logical reason for requiring them to have liability insurance. But being on the active list would probably make it easier for such a person to find employment in the practice of law.

- The Law Society should encourage members to retain their active status by initiating a category which does not require trust account accounting. Many forms of practice do not require trust accounts. Also, either the fees should be reduced (especially for new members) or the insurance should be optional. Currently the fees are much too high to be a practising member unless you are employed with a firm or have an established practice.

- I think people should be encouraged to maintain their active status. There could be some category of those who would continue their education, either formally or informally through LESA seminars, CBA meetings and subsections, or other courses.

- I would like to have active status but since I'm on disability I can't afford insurance, etc.

- The Law Society should encourage members to remain active in the sense of using their legal skills. If more than lip service is to be paid to the idea that lawyers should contribute to society as well as pursue a business there are some changes that could be made. There are a large number of unemployed, underemployed or otherwise employed lawyers in the province at any give time. Many of these would be happy to donate their legal services to various charities and community organizations. I can understand the rationale for requiring that insurance be paid before that is done but to add the trouble and expense of complying with the accounting requirements is unreasonable. If the statutory declaration of a corporate employee that he or she is not handling monies is sufficient, why isn't the statutory declaration of an unemployed or otherwise employed lawyer that he or she won't handle monies in the course of donating services to charitable works adequate?

In addition, why doesn't the Law Society give some thought to providing blanket insurance coverage to Calgary Legal Guidance so that lawyers who are not otherwise practising could continue to donate their time and skills to that organization?...

\section{Men wrote:}

-... In my present position, I could fairly say that I am as capable and competent to return to practice as if I were currently in practice. Yet after a certain time on the inactive list I am subject to possibly being required to re-write the bar exams. To avoid this, I could return to the active list, but in reality all this would amount to is my paying for a privilege that has absolutely no rational connection with my payment of fees. I feel that consideration should be given to creating a differential level of fees for members who are "active" in the sense of being employed in the legal field, but who are not "practising" in the sense of advising clients or handling trust monies. I would gladly pay more than the current "inactive" fee of $\$ 65.00$, yet I think it would be unfair for me to pay the same fee as those members who do advise clients and handle trust monies as it is the latter group that creates the bulk of the financial demands upon the Law Society. 
- I would like to see some sort of semi-active category such as the FEI does but the question of insurance is tricky, i.e. how can you be a little bit pregnant. Insurance company at the moment is very inflexible and cost me money at no risk to the funds. Can't suggest any changes to legal profession.

- Lawyers elected to Parliament or the legislature should be able to remain on the active list but be relieved of paying the assurance and insurance premiums if they agree not to take on clients, etc.

Some lawyers pay their full active fees and insurance to the Law Society when they are not practising law, in order to ensure that they will not be required to re-write bar admission exams. Some of the respondents were of the view that this system was unfair, because it was based on ability to pay and not on competence. Comments, the first by a woman and the second by a man, included:

- Not to "retain" but to "regain" their status, yes. As I understand the present system, an inactive lawyer either goes on the inactive list or pays the annual premium to stay on the active list. This is unfair to the inactive lawyer and the public he or she might eventually serve. It does not ensure that the lawyer returning to practice is sufficiently up-to-date. It only encourages non-practising lawyers to shell out the premium to stay on the active list and thereby avoid the dreadful possibility of repeat Bar Ad exams.

I propose a system in which non-practising lawyers may not remain on the list simply by paying their annual dues. They must be put on the inactive list and permitted to rejoin the active list after or while completing a refresher course (videos and assignments and resource lawyers) offered by the Law Society/LSEA.

- If not actually practising I would disallow paying as active member. Out of sight - out of mind.

Two additional men suggested a fee and insurance reduction for first year practitioners. Related to the above comments, were comments by a man who preferred a gradual retirement process:

- I would prefer to be practising as a sole practitioner on a part-time basis.

I would like to remain involved in the practice of law but would prefer to "slow down" and not have the pressures and stresses of a full blown practice.

However, Law Society fees and insurance and necessary memberships and necessary accounting and administrative overhead presents me from doing so. I estimate my basic annual cost of remaining in practice to be $\$ 5000$ which means that the first $\$ 5000$ that I would earn nets nothing to me as my fees and overhead are substantially the same as a full-time practitioner who perhaps handles millions of dollars and has gross annual fees in excess of $\$ 250,000$.

I have practised for $\mathbf{4 0}$ years, have had no claims and not so much as an investigation for wrong doing or negligence. Surely some arrangement should be made so I can continue to be involved without suffering a financial loss.

Perhaps fees should be lowered or waived and insurance waived. Perhaps some limitation could be placed on my practice under those circumstances. As an "inactive" member I cannot properly advise my friends or relatives nor look after my own business affairs without risking an investigation and charge by the Law Society.

I think insurance rates are not properly graduated to reflect the risks involved in smaller and part-time practices. In spite of the lost experience set out above, my premiums have continually gone up - not down. After $\mathbf{4 0}$ years it is most unlikely that I would change my style of practise and become "high-risk." 
Perhaps insurance premiums should be based on the last years "gross fees" of the practitioner. Somehow it should be based on work-done or fees charged as this has a direct relation to the risks involved.

When involved in a busy practice in earlier years I had always looked forward to the time when I could go "part-time," be selective in my practice and have time for other pursuits and recreation. But I cannot afford to pay $\$ 5000$ per year for this privilege.

\section{Another man suggested a new section for retired members:}

- Set up a "Retired Members" Section with nominal dues so we can keep in touch with the profession via publications, etc. The present "non-practising status" is ok but should have a section. Could have luncheons and social gatherings.

Some of the comments were tied to assisting women who have families. A woman commented that "women who leave to have a family should be encouraged to be active members."

\section{Need for Balance and Flexibility for Family Commitments}

A number of respondents wanted changes in the profession which would allow them to have more balanced lives and time for family and other activities. Women commented:

-... The concept of a balanced life must become acceptable in actual practice. At the moment it is used merely to garnish Canadian Bar Association dinner speeches.

-... More should be done to accommodate changing lifestyles and family commitments. I found the courts particularly unwilling to take family priorities into consideration for counsel. I also found the stress and adversarial nature of law practice difficult to combine with nurturing a family. Some attention in law school or the bar course should be given to keeping perspective for oneself and other lawyers..

- Realistic expectations regarding hours. Most of us, especially juniors: a) don't have wives, and b) do have lives...

- Another general comment: that there are other ways to practise law than the prevailing one is true. I enclose a copy of a story on a feminist firm from the Ontario Lawyers Weekly. The interesting point about the article, at least in so far as it relates to the survey, isn't the feminist views of the lawyers involved so much as the way in which thier feminism informs their office management - e.g. time commitment.

- Greater flexibility is required to allow people to devote time to both careers AND FAMILY.

- Dear Sir: I have taken the opportunity to answer this questionnaire although I became active [recently]. I have been inactive for the past two and one half years and did not wish to be placed in a position where I would have to rewrite my bar exams. I am presently working for ... The pay is poor, but it keeps me current in the law and permits me the flexibility I require to run a household with three small children. When I was "practising law" I was primarily involved in litigation. It is virtually impossible to find parttime job sharing with any hours, let along flexible hours, in litigation. 
-... I am not sure the Law Society has a role in dealing with the problem that most women with children face in the practice of law - namely the hourly demands and the more subtle pressures of a maleoriented profession. However, I expect that despite near $50 \%$ female law school graduates, the number of women who continue in private practice drops dramatically, especially for those with children.

I could go on, however, I have more pressing and more immediate concerns than this survey which I expect will reveal nothing new.

- Firms need to realize that just because a person has a family life he/she is still valuable as a member.

\section{A man commented:}

- I don't know how, but somehow the profession has got to come to grips with the need to balance one's personal and professional life. I work to live. I do not live to work. The sacrifices demanded by the profession were simply more than I was prepared to make.

Some respondents pointed to the need for part-time practice. Comments by respondents, the first two by women and the third by a man, included:

- It would be desirable for the profession to accommodate part-time work.

-...It would be most helpful to have the opportunity to work fewer hours or to encourage work sharing even if it means less money. Some of us value other aspects of life other than full-time work and then household chores, etc...

- Lawyers should be able to practice law part-time, but its not economically feasible.

One woman, who was let go from a position because her employer wanted someone to work full-time for the same rate of pay she was receiving for part-time work, commented:

-... I think it is very difficult for women to work part-time at an active litigation practice. Where it does occur hourly remuneration is much lower than it would be for full-time employment. There is, in my opinion, a mind set in management of law firms which holds that part-time employment is economically unsound. Billable hours rule and the thought of an empty desk makes management shudder. This is not a reflection of our economic times. It holds true good times and bad. Law is a business with very little flexibility.

\section{Continuing Education and Re-Entry Courses}

A number of suggestions for reform dealt with continuing education and courses for re-entry into the practice of law. Comments by women included:

-... I propose a system in which non-practising lawyers may not remain on the list simply by paying their annual dues. They must be put on the inactive list and permitted to rejoin the active list after or while completing a refresher course (videos and assignments and resource lawyers) offered by the Law Society/LSEA. 
- Voluntary "reentry" courses to facilitate feeling of competence (please!) — to help "retrain" in new areas of practice.

- I would like to see the Law Society offer courses to assist inactive members to become current in the law following a leave. I have not practised for 4 years and realize I need a refresher.

- With increased liability concerns it would be good to have something to help keep the legal mind tuned and current.

- Some credit should be given for part-time law related work vis a vis the requalification requirement.

To resume active practice after a break (for raising children or other reason) should perhaps be facilitated by a mini-re-admission program, i.e., a take-home update course in certain areas or a series of lectures (perhaps on tape) for this purpose.

- I would like to see refresher courses run for women which would: a. give them confidence to return to practice after time off; $b$. bring them up to speed on new laws and cases; c. draw attention to this vital part of the workforce to the rest of the profession. Such courses would have to be subsidized because presumably most women would not have jobs at the time.

\section{Career Advice}

There were a number of suggestions regarding advice on career and practice. Women suggested:

- Much more support for professional development is required. People may learn the law at law school but they don't learn how to be lawyers - i.e. promotional work, client management, etc. Yet, much of success as a student depends more on latter than on former.

- Thanks for seeking my opinion - the Law Society could perhaps help by having available information about law options other than full-time practice.

- Students should be given more aid in seeking alternative opportunities to practice.

\section{Men suggested:}

- I would really like to see a "Global Interest" inventory specifically designed for lawyers, i.e. a personality inventory which would match personalties to various types of practice. Family to corporate "brand name" to "personal."

- Require better placement facilities.

- Run more seminars on job search strategies, on setting up your own practice.

\section{Too Many Lawyers}

Four men and two women suggested that there should be more control over the number of law students and lawyers. The women commented: 
- The Law Society must take an active role in limiting the number of yearly law school graduates. The market is simply saturated - Canada wide.

-... The Law Society has an obligation to address [the oversupply of lawyers] immediately. The University of Victoria and the University of Calgary law schools were opened for political reasons. I have taught over 14,000 [pre-law] students in this province. Approximately one hundred of these students became lawyers... $A$ lot of students are extremely bitter at the over supply of lawyers and the difficulty they have in obtaining articling positions or any position with any law firm. These feelings will only accelerate as the recession deepens.

\section{Act on Discrimination}

\section{A woman suggested that the Law Society should:}

- Continue to promote programs to assist lawyers in a dispute i.e. sex harassment, being paid! Helping those with stress, alcohol, etc. problems... I would like the profession to mediate when there are sexually discriminating practices and take some action without jeopardizing the woman's position within the firm.

\section{Ethics}

One man suggested that the Law Society "raise ethical standards and enforce them." He continued:

- The Law Society is clearly (and rightly) concerned about the ethical standards in the profession and keeps asking for input. I gave some input some time ago ... but did not even get the courtesy of a reply. I really feel that the society is not prepared to consider changes that are required i.e. with teeth in them. I could have given you a marvellous example of what I think was pathetic incompetence caused by intellectual dishonesty. My letter ... suggested concrete reforms to hit this sort of thing on the head, but it involved reigning in the mindless and unscrupulous adversary system outside the courthouse and I guess that was asking too much, of modern practice which is no longer interested in truth and fair play but only in winning. This results in losers and we are totally failing society, which is already trying to bypass us in many areas.

\section{Articling}

A number of respondents were concerned with the articling system. The first two comments are by women, the third by a man:

- The Law Society needs to help insure that students receive a decent articling experience. I felt that I could not go to anyone within the firm and complain about what was happening to me for two reasons. First, I would be labelled a whiner. Second, I would be ignored anyway. In any dispute, the firm is going to support a top billing lawyer such as my principal, rather than a student.

- Articling students should have greater job guarantees or termination benefits; currently the view that students don't even get the minimum standards stipulated in the Employment Standards Code is, to say the least, straight from Charles Dickens. 
- The senior practitioners and large law firms of this province have abrogated their responsibility to retain articling students and young lawyers long enough in order for them to obtain appropriate experience and in addition, generate and establish their own practices. These lawyers, who had their "heyday" during the 1970 s, only care about maintaining or increasing their income and cast aside the younger members of the bar's welfare.

\section{Other Suggestions}

Other suggestions, all by men, included:

- Allow us to advertise!! Advertising is the only way a young lawyer can hope to survive.

- Permanent associate positions.

- Lawyers make too much money on litigation and insufficient amounts on solicitor's matters. The courts system should be streamlined so litigation is more efficient, expeditious and economical so costs are saved. On the other hand lawyers should be able to bill more for real estate and wills and those cost cutting lawyers should be strictly monitored and reprimanded for unprofessional and poor quality service because they do cut the quality of service they provide. As a result those lawyers harm not only the reputation of other lawyers (by association) but their ability to generate a sufficient income...

The profession and the Law Society have the responsibility to ensure that all policies are directed to helping all lawyers make a decent living. Changes must occur regarding retaining clientele, division of firm receipts, and other so-called business policies of legal practices so propounded and condoned by the profession.

It is also about time that the Law Society and legal profession got the message out to the public that lawyers who have either practised in small or rural law firms are just as competent as those lawyers from the large firms.

\section{CONCLUDING REMARKS}

Recent studies across Canada have shown that women leave the practice of law in a greater proportion than men, although usually not in as great a number. This study was designed, in part, to describe this phenomenon in Alberta, to examine the reasons behind it, to determine if women had encountered problems which differed from those encountered by men, and to ascertain what could be done by the Law Society and the legal profession to better accommodate respondents who had transferred to non-practising status. This paper examined the responses of three groups: the women who were called to the Bar in 1978 or later, the men who were called in 1978 or later, and the men called before 1978. There were interesting differences and similarities between the women and the $78+$ men, and between the two different groups of men. A number of concerns expressed by these non-practising members are addressed in these concluding comments.

\section{A. INFLEXIBILITY IN THE LEGAL PROFESSION}

Both women and men who responded to this survey, and to the survey of active members of the Law Society of Alberta, expressed concerns about the difficulties associated with combining a family life with the practice of law. Just over $60 \%$ of the 
women and $44 \%$ of the $78+$ men in this survey expressed dissatisfaction with the balance between their work and personal life when they were last practising law in Alberta. ${ }^{50}$ Lack of accommodation for family commitments was seen as a form of bias against women in the legal profession by $64.6 \%$ of the women and $23.3 \%$ of the men in the survey of active members, ${ }^{51}$ and by $72.7 \%$ of the women, $39.3 \%$ of the $78+$ men, and $30.6 \%$ of the pre- 78 men in this survey. This lack of accommodation was also seen as the most prevalent form of bias against men by the women (14.3\%) and the 78+ men (21.5\%) in this study. In the active members survey, $15.0 \%$ of the women and $11.1 \%$ of the men indicated that lack of accommodation for family commitments was a form of bias against men in the legal profession. ${ }^{52}$

Child care work is still largely the responsibility of women in our society. In the survey of active members of the Law Society of Alberta, women who were working full-time spent a median of 35.0 hours a week on childcare, while the men spent a median of 15.0 hours. ${ }^{53}$ In this survey, $41.9 \%$ of the women, only $8.0 \%$ of the $78+$ men and none of the pre-78 men indicated that child care commitments influenced their decision to transfer to the non-practising list. ${ }^{54}$

The entrance of women into the profession and the increase in dual income families have led to a need to rethink the membership arrangement. Accommodation for members with family commitments requires a joint effort between the Law Society and the legal profession. For example, job sharing and part-time work in the legal profession is expensive without the availability of part-time fees and part-time insurance. In 1992, the Law Society of British Columbia, following recommendations from its Subcommittee on Women in the Legal Profession, ${ }^{55}$ introduced an insurance fee discount for part-time practitioners.

The circulation to law firms of model policies, which outline alternative types of practices, parental leave and career breaks, will also be of assistance to both individual

A substantially smaller proportion of women (22.3\%) and men (19.1\%) in the survey of active members expressed dissatisfaction with the balance between their work and personal life. $J$. Brockman, Identifying the Issues: A Survey of Active Members of the Law Society of Alberta (Calgary: Law Society of Alberta, 1992) at 34.

s1 "Bias in the Legal Profession" supra note 10 at 792.

S2 Ibid.

s3 lbid. at 761 .

s4 This is similar to a survey of male readers by the Quebec business magazine, Affaires Plus, where only $6.8 \%$ of the men said they would make sacrifices in their careers to improve their family lives. Interestingly, $\mathbf{7 7 . 6 \%}$ of these men said their family was their top priority. W. Clements, "Statistical Lore for Everyday Living" (July, 1993) Report on Business Magazine 160.

55 Women in the Legal Profession Subcommittee, Women in the Legal Profession: A Report of the Women in the Legal Profession Subcommittee by K.P. Young, D.L. Smith, F. Watters, K. Nordlinger, Q.C., W. Wilson, \& M. O'Brien (Vancouver: Law Society of British Columbia, September, 1991) at 13. These recommendations were endorsed by Hughes et al., supra note 49 Volume 1 at 3-20, who also recommended that firms and other legal employers adopt a Model Policy for Alternative Work Arrangements which appears in Appendix A of Volume 1 of their report. 
practitioners and law firms. ${ }^{56}$ The Law Society of Alberta's Alternative Work Schedules, Guidelines for Law Firms provides a sample policy for firms, as well as some background information which dispels many of the myths surrounding alternative work schedules. For example, "the American literature suggests that lawyers working alternative work schedules are often more productive on a pro rata basis than their full-time colleagues." It also points out that alternate work schedules can be adapted to any area of the law.

The British Columbia Gender Bias Committee recommended that the Law Society of British Columbia "conduct periodic surveys of parental leave policies ... and publish the information to members, articled students, and law students. ${ }^{157}$ Widespread publicity of these policies is key to their success.

While many of these initiatives will have some impact on the lives of parenting lawyers, little will change unless we also recognize the "hidden" issues in the relationship between paid work and family work. Professor Mary Jane Mossman identifies three of these issues: 1) the nature and organization of legal work, 2) the impact of gendered societal expectations for women and men, and 3) the scope of "familial" responsibilities within the legal profession. ${ }^{58}$

The nature and organization of legal work has historically reflected a "system of gender privilege" where men, but not women, have spouses who cater to all of their home and family needs while they conform to the "life pattern of the typical workaholic father. ${ }^{.59}$ So long as traditional expectations for women and men persist, women lawyers will continue to find themselves in the proverbial double bind. ${ }^{60}$ Mossman suggests that we spend less time thinking about where women can fit into the legal profession (for example moving to government positions) and more time rethinking the gendered structure of legal work. ${ }^{61}$ Until this occurs, ${ }^{62}$

Ibid. See supra note 16 for policies made available by the Law Society of Alberta, and Kay, supra note 23 for recommendations made to the Law Society of Upper Canada.

37 Hughes et al., supra note 49.

ss These "hidden" issues are discussed in detail by M.J. Mossman, "New Directions" supra note 43. See also M.J. Mossman, "Gender Bias and the Legal Profession: Challenges and Choices" in J. Brockman and D.E. Chunn, Investigating Gender Bias: Law, Courts and the Legal Profession (Toronto: Thompson Educational Publishing, 1993).

J.C. Williams, "Sameness Feminism and the Work/Family Conflict" (1990) 35 New York School Law Review 347 at 352-353 as quoted in "New Directions" ibid. at 11.

"New Directions," ibid. at 15-21. See also M.J. Mossman, "'Invisible' Constraints on Lawyering and Leadership: The Case of Women Lawyers" (1988) 20 Ottawa L. Rev. 567.

The downside to the present system is that "those who rise to the top ... are among those who have had the least experience of all in raising children" and are therefore least likely to have the human capacity to make important socictal decisions. S. Moller Okin, Justice, Gender and the Family (New York: Basic Books, 1989) at 127 as quoted in "New Directions" ibid. at 13. Mossman explores a number of alternatives, some of which are presently being considered by law societies and law firms across Canada. She also examines the suggestion by Joan Williams that the solution is to directly "challenge the gendered structure of wage labour." Ibid. at 44.

"New Directions," ibid. at 47. 
...those who remain in the profession, and especially in large law firms, are more likely to be those who conform most closely to the traditional concept of "ideal worker," a person without significant family responsibilities: men much more often than women.

\section{B. LAW SOCIETY FEES AND RE-ENTRY}

Two concerns emerged from some of the respondents' comments regarding Law Society fees and re-entry into the practice of law. The first has to do with the arbitrary distinction between members who transfer to the non-practising list and those who remain on the active list while not practising law. After three years on the non-practising list, a lawyer has to apply to the Law Society to become an active member and risk being required to write exams, while those lawyers who continue to pay their active membership fees while not practising law are not scrutinized. ${ }^{63}$ The British Columbia Subcommittee recommended a policy which would eliminate the "arbitrary distinctions between those not practising law who can afford to pay fees, and those who cannot."164 The Subcommittee also recommended that persons returning to practice after three years be assessed on an individual basis. ${ }^{65}$

The other concern of some of the respondents was that re-entry into the practice of law is difficult after one has been on the inactive list for any length of time. A number of respondents suggested re-entry courses, coordinated by the Law Society and the Legal Education Society of Alberta. Similar suggestions were made by the British Columbia committees. $^{66}$

\section{DISCRIMINATION IN THE LEGAL PROFESSION}

There is a widespread perception among active and non-practising members of the Law Society of Alberta that there is gender bias in the legal profession. Almost all of the women respondents $(97.2 \%$ of the active members and $97.4 \%$ of the non-practising members) and more than three quarters of the men (77.6\% of the active members, $83.9 \%$ of the $78+$ men, and $75.0 \%$ of the pre- 78 men in this survey) were of the view that there was some form of gender bias against women in the legal profession.

Career advancement was most frequently identified by the women $(81.8 \%)$ and men $(60.7 \%$ of the $78+$ men and $38.9 \%$ of the pre-78 men) in this survey, and by the women $(81.8 \%)$ and men $(42.4 \%)$ in the active members survey ${ }^{67}$ as areas in which women are

British Columbia does not presently have a non-practising membership category and the Benchers have recently indicated they will seek changes to the Legal Profession Act, S.B.C. 1987, c. 25 to introduce a non-practising membership category. See (January-February, 1993) Benchers' Bulletin 1. This will not eliminate the problem as expressed by the respondents in this survey.

ot Young et al., supra note 55 at 22.

as Ibid. at 22. The Ontario Committee recommended that policies concerned resignations, reinstatements and readmissions be studied "to determine whether there are ways to reduce barriers to the resumption of active practice." Kay, supra note 23 at 112.

to Young, et al., ibid. at 46. Hughes et al., supra note 49 at 3-22. The Ontario Committee recommended further study in this area: Kay, ibid.

67 "Bias in the Legal Profession" supra note 10 at 755. 
discriminated against. Attaining partnership was the next most frequently identified sphere in which women were discriminated against. Over half of the women (54.2\%) and $24.2 \%$ of the men in the active members survey, ${ }^{68}$ and $57.1 \%$ of the women, $33.9 \%$ of the $78+$ men, and $27.8 \%$ of the pre- 78 men in this survey thought that women were discriminated against in the legal profession when it came to hiring.

The Law Society of Alberta recently developed Draft Guidelines for Equality in Employment Interviews, which discusses the relevance of the Alberta Individual's Rights Protection Act and makes suggestions for avoiding discrimination in job interviews. ${ }^{69}$ The document also refers to lawyers' professional obligations under the Professional Code of Conduct and the draft of a proposed Code which prohibits discrimination on the basis of "race, creed, colour, national origin, gender, religion, marital status, sexual orientation, age, mental or physical disability or any similar personal attribute." The Guidelines are available upon request from the Law Society.

\section{ALTERNATIVE CAREERS FOR LAWYERS}

Advice on alternative career paths for lawyers (suggested by a number of respondents in this survey) may be more beneficial to some members than plans to encourage them to remain in the practice of law. The Ontario Committee recommended that the Law Society of Upper Canada provide members with information on legal careers in areas other than private practice and that:

[S]teps be taken to make it more widely known, at every stage of the educational process, that opportunities exist, both inside and outside the legal profession, for using a law degree in careers other than the traditional private practice of law. ${ }^{70}$

Seminars such as the one on "Career Options: Breaking Away in the 1990s," sponsored by the Law Society of Alberta and the Legal Education Society of Alberta, should be very beneficial to those active and inactive members looking for alternatives to the practice of law. ${ }^{71}$

In conclusion, this paper has identified some of the concerns of nonpractising members of the Law Society of Alberta and some of the steps that have been taken by the Society to deal with barriers women encounter in the legal profession. These actions should benefit both women and men in the legal profession, and the profession itself. As Madame Justice Bertha Wilson recently said, "We cannot address inequality in the legal system or society at large, with any credibility, unless we first put our own house in order." ${ }^{172}$

Ibid.

The document also sets out a list of questions which the Alberta Human Rights Commission recommends employers avoid asking and guidelines for lawful and equitable interviews. The Benchers have also published an article on "Employment-Related Sexual Harassment" and the Gender and Inequality in the Legal Profession Committee is developing a sample policy on sexual harassment. See "Employment-Related Sexual Harassment" (July, 1992) Benchers' Advisory at 4-5. Kay, supra note 23 at 109.

A description of the seminar is contained in (July, 1992) 27 Bencher's Advisory 1.

S. Bindman, "Rooting Discrimination out of the Legal System" (September, 1991) National 3. 


\section{TABLES 1-17}

TABLE 1

\section{Lawyers and Notaries in Canada, 1986-1991}

1986

Men

Women

Ratio

of Women

of both

Increase of Women

as a Percentage

of Total Increase

1986-1991

$16 \%$

$71 \%$

$28 \%$

$55.8 \%$
$32,835(78.2 \%)$

$9,145(21.8 \%)$

3.6:1

2.4:1

1991

37,965 (70.9\%)

$15,610(29.1 \%)$

These figures are from Statistics Canada, Occupation (Ottawa: Statistics Canada, 1993) no. 93-327 at 8. The category "lawyers and notaries" includes all lawyers in Canada and notaries in Quebec and British Columbia. 
TABLE 2

Lawyers in Alberta, 1986-1991 ${ }^{1}$

1986

Men

Women

Ratio

3.2:1

$3,260(76.3 \%)$

$1,010(23.7 \%)$

1986-1991

Percentage Increase

of Men

of Women

of both

Increase of Women

as a Percentage

of Total Increase
$1,245(24.5 \%)$

1991

$3,840(75.5 \%)$

$3.1: 1$
$18 \%$

$23 \%$

$19 \%$

$28.8 \%$

1 These figures are from Statistics Canada, Occupation (Ottawa: Statistics Canada, 1993) no. 93-327 at 187. 


\section{TABLE 3}

Women and Men Called To the Bar In Alberta, 1915-1969 by Year of Call ${ }^{1}$

Year

Called

1915-1919

1920-1924

1925-1929

1930-1934

1935-1939

1940-1944

1945-1949

1950-1954

1955-1959

1960-1964

1965-1969
Women

$2(1.2 \%)$

$11(5.5 \%)$

3 (3.1\%)

$4(7.4 \%)$

$5(6.3 \%)$

4 (7.3\%)

$1(1.0 \%)$

$4(1.4 \%)$

8 (2.7\%)

$14(4.0 \%)$

$20(5.2 \%)$
Men

$171(98.8 \%)$

$190(94.5 \%)$

94 (96.9\%)

$50(92.6 \%)$

75 (93.7\%)

$51(92.7 \%)$

98 (99.0\%)

$285(98.6 \%)$

293 (97.3\%)

337 (96.0\%)

$366(94.8 \%)$ 
TABLE 4

Women and Men Called To the Bar In Alberta 1970-1991 by Year of Call ${ }^{1}$

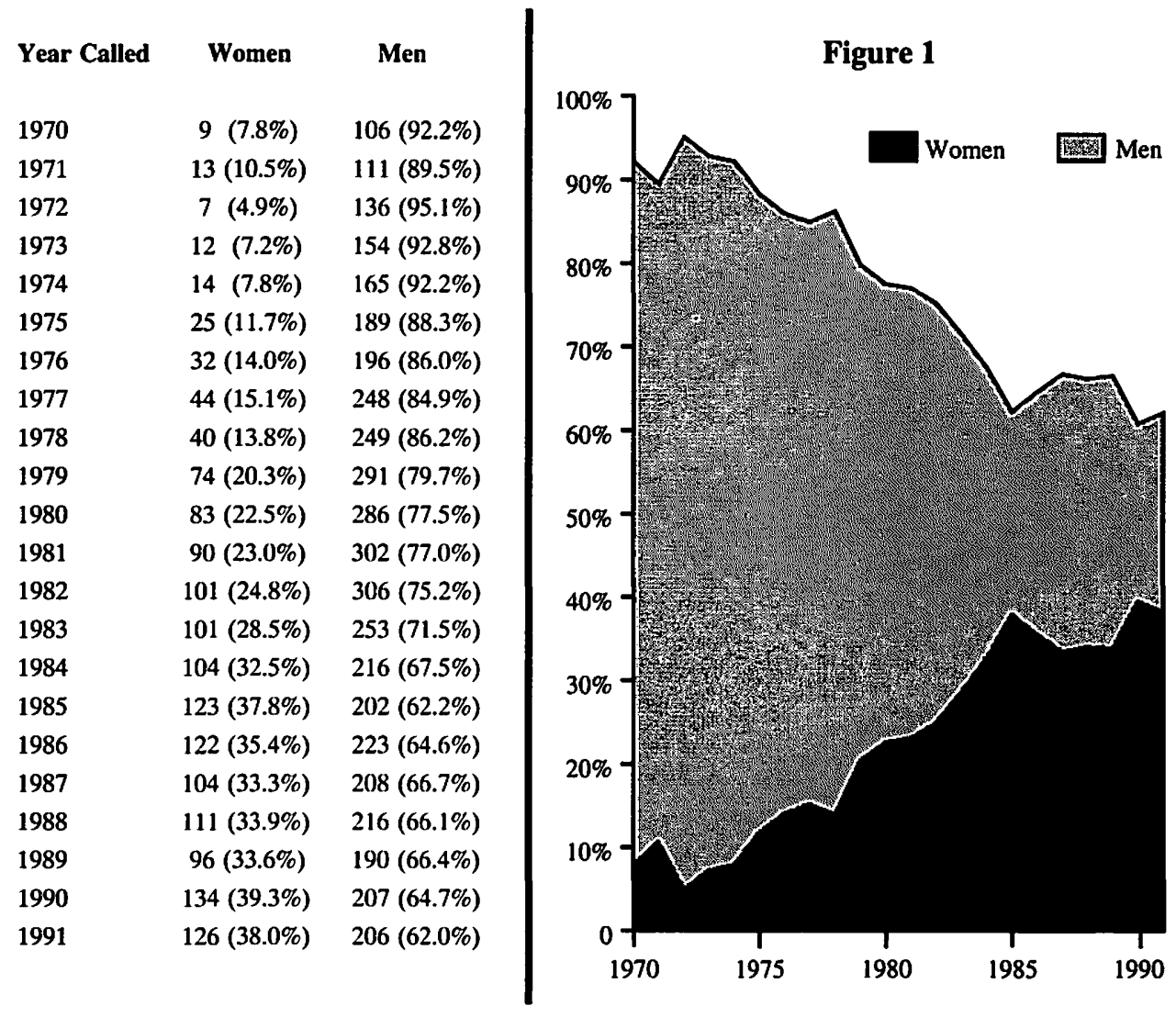

1 These are the data for Figure 1. Numbers are from the Law Society of Alberta. 


\section{TABLE 5}

\section{Where Members of the Law Society of Alberta Work ${ }^{1}$}

Women

557 (57.3\%)

$138(14.2 \%)$

$11(1.1 \%)$

$156(16.0 \%)$

$110(11.3 \%)$

$972(100 \%)$
Men

$2604(68.2 \%)$

$601(15.7 \%)$

With a Sole

Practitioner

Companies and

Corporations

Government

TOTAL
$9 \quad(.2 \%)$

$348 \quad(9.1 \%)$

$255(6.7 \%)$

3817 (100\%) 


\section{TABLE 6}

\section{Admissions to the University of Calgary Law School ${ }^{1}$}

\begin{tabular}{|c|c|c|}
\hline Year & Women & Men \\
\hline 1978 & $23(38.3 \%)$ & $37(61.7 \%)$ \\
\hline 1979 & $30(50.0 \%)$ & $30(50.0 \%)$ \\
\hline 1980 & $23(45.1 \%)$ & $28(54.9 \%)$ \\
\hline 1981 & $32(43.4 \%)$ & $23(56.6 \%)$ \\
\hline 1982 & $35(51.5 \%)$ & $33(48.5 \%)$ \\
\hline 1983 & $25(39.7 \%)$ & $38(60.3 \%)$ \\
\hline 1984 & $23(38.3 \%)$ & $37(61.7 \%)$ \\
\hline 1985 & $27(44.3 \%)$ & $34(55.7 \%)$ \\
\hline 1986 & 27 (44.3\%) & $34(55.7 \%)$ \\
\hline 1987 & $36(55.4 \%)$ & $29(44.6 \%)$ \\
\hline 1988 & $38(57.6 \%)$ & $28(42.4 \%)$ \\
\hline 1989 & $40(58.8 \%)$ & $28(41.2 \%)$ \\
\hline 1990 & 34 (45.9\%) & $40(54.1 \%)$ \\
\hline 1991 & $44(64.7 \%)$ & $24(35.3 \%)$ \\
\hline
\end{tabular}


TABLE 7

\section{Admissions to University of Alberta Law School ${ }^{1}$}

$\begin{array}{lcr}\text { Year } & \text { Women } & \text { Men } \\ 1950-1959 & 28(4.2 \%) & 634(95.8 \%) \\ 1960-1969 & 70(9.2 \%) & 691(90.8 \%) \\ 1970 & 15(9.6 \%) & 141(90.4 \%) \\ 1971 & 25(13.8 \%) & 156(86.2 \%) \\ 1972 & 32(17.5 \%) & 151(82.5 \%) \\ 1973 & 28(16.8 \%) & 139(83.2 \%) \\ 1974 & 31(20.0 \%) & 124(80.0 \%) \\ 1975 & 48(25.1 \%) & 143(74.9 \%) \\ 1976 & 42(25.1 \%) & 125(74.9 \%) \\ 1977 & 40(24.2 \%) & 125(75.8 \%) \\ 1978 & 53(30.6 \%) & 120(69.4 \%) \\ 1979 & 62(35.2 \%) & 114(64.8 \%) \\ 1980 & 67(37.4 \%) & 112(62.6 \%) \\ 1981 & 69(37.7 \%) & 114(62.3 \%) \\ 1982 & 62(36.5 \%) & 108(63.5 \%) \\ 1983 & 68(39.1 \%) & 106(60.9 \%) \\ 1984 & 70(39.5 \%) & 107(60.5 \%) \\ 1985 & 66(36.5 \%) & 115(63.5 \%) \\ 1986 & 81(45.5 \%) & 97(54.5 \%) \\ 1987 & 70(38.0 \%) & 114(62.0 \%) \\ 1988 & 75(41.7 \%) & 105(58.3 \%) \\ 1989 & 71(41.8 \%) & 99(58.2 \%) \\ 1990 & 70(41.7 \%) & 98(58.3 \%) \\ 1991 & 75(41.7 \%) & 105(58.3 \%)\end{array}$

'The numbers were compiled by Mr. Gary Wood, Business Analyst, Office of the Registrar, University of Alberta from the University of Alberta Summary of Statistics publication. 
TABLE 8

Number of Graduates From University of Calgary Law School'

\begin{tabular}{|c|c|c|}
\hline Year & Women & Men \\
\hline 1979 & $17(34.0 \%)$ & $33(66.0 \%)$ \\
\hline 1980 & $21(37.5 \%)$ & $35(62.5 \%)$ \\
\hline 1981 & $22(37.9 \%)$ & $36(62.1 \%)$ \\
\hline 1982 & $25(53.2 \%)$ & $22(46.8 \%)$ \\
\hline 1983 & $22(43.1 \%)$ & $29(56.9 \%)$ \\
\hline 1984 & $29(54.7 \%)$ & $24(45.3 \%)$ \\
\hline 1985 & $31(53.4 \%)$ & $27(46.6 \%)$ \\
\hline 1986 & $20(34.5 \%)$ & $38(65.5 \%)$ \\
\hline 1987 & $23(41.1 \%)$ & $33(58.9 \%)$ \\
\hline 1988 & $23(43.4 \%)$ & $30(56.6 \%)$ \\
\hline 1989 & 24 (51.1\%) & $23(48.9 \%)$ \\
\hline 1990 & $33(52.4 \%)$ & $30(47.6 \%)$ \\
\hline 1991 & $38(56.7 \%)$ & $29(43.3 \%)$ \\
\hline
\end{tabular}

I Numbers from the Faculty of Law, University of Calgary. 


\section{TABLE 9}

\section{Number of Graduates From University of Alberta Law School ${ }^{1}$}

\begin{tabular}{|c|c|c|}
\hline Year & Women & Men \\
\hline 1914-1919 & $1(2.1 \%)$ & 47 (97.9\%) \\
\hline $1920-1929$ & $12(6.7 \%)$ & $167(93.3 \%)$ \\
\hline $1930-1939$ & $14(10.0 \%)$ & $126(90.0 \%)$ \\
\hline $1940-1949$ & $3(2.3 \%)$ & $129(97.7 \%)$ \\
\hline $1950-1959$ & $11(3.4 \%)$ & $315(96.6 \%)$ \\
\hline $1960-1969$ & $30(7.3 \%)$ & $379(92.7 \%)$ \\
\hline 1970 & $7(9.5 \%)$ & $67(90.5 \%)$ \\
\hline 1971 & $6(6.9 \%)$ & $81(93.1 \%)$ \\
\hline 1972 & $16(13.7 \%)$ & $101(86.3 \%)$ \\
\hline 1973 & 14 (11.8\%) & $105(88.2 \%)$ \\
\hline 1974 & $16(10.5 \%)$ & 137 (89.5\%) \\
\hline 1975 & $26(17.4 \%)$ & $123(82.6 \%)$ \\
\hline 1976 & $21(13.6 \%)$ & $133(86.4 \%)$ \\
\hline 1977 & $21(16.9 \%)$ & $103(83.1 \%)$ \\
\hline 1978 & $39(22.9 \%)$ & $131(77.1 \%)$ \\
\hline 1979 & $38(24.5 \%)$ & $117(75.5 \%)$ \\
\hline 1980 & $40(26.8 \%)$ & $109(73.2 \%)$ \\
\hline 1981 & $47(29.2 \%)$ & $114(70.8 \%)$ \\
\hline 1982 & $52(32.3 \%)$ & $109(67.7 \%)$ \\
\hline 1983 & $64(38.8 \%)$ & $101(61.2 \%)$ \\
\hline 1984 & $60(36.8 \%)$ & $103(63.2 \%)$ \\
\hline 1985 & $62(38.3 \%)$ & $100(61.7 \%)$ \\
\hline 1986 & $56(37.3 \%)$ & $94(62.7 \%)$ \\
\hline 1987 & $58(37.4 \%)$ & $97(62.6 \%)$ \\
\hline 1988 & $62(38.0 \%)$ & $101(62.0 \%)$ \\
\hline 1989 & $75(46.0 \%)$ & $88(54.0 \%)$ \\
\hline 1990 & $61(37.0 \%)$ & $104(63.0 \%)$ \\
\hline 1991 & $71(43.8 \%)$ & $91(56.2 \%)$ \\
\hline
\end{tabular}

The numbers were compiled by Mr. Gary Wood, Business Analyst, Office of the Registrar, University of Alberta. Statistics from 1914 through 1987 were obtained from paper records maintained by the Convocation Officer, and statistics from 1988 through 1991 came from the University of Alberta Summary of Statistics publication. 
TABLE 10

\section{Attrition Rates of Women and Men Called in Alberta between 1936-1990, as of May 1, 1991 ${ }^{1}$}

Number Called

Number In Good

Standing, 1991

\begin{tabular}{|c|c|c|c|c|c|c|}
\hline $\begin{array}{l}\text { Years of } \\
\text { Call }\end{array}$ & Women & Men & Women & Men & Women & Men \\
\hline $1936-1940$ & 6 & 87 & 0 & 8 & $6(100 \%)$ & $79(91 \%)$ \\
\hline $1941-1945$ & 3 & 40 & 0 & 4 & $3(100 \%)$ & $36(90 \%)$ \\
\hline $1946-1950$ & 0 & 118 & 0 & 23 & $0(0 \%)$ & $95(81 \%)$ \\
\hline $1951-1955$ & 4 & 313 & 1 & 88 & $3(75 \%)$ & $225(72 \%)$ \\
\hline $1956-1960$ & 9 & 300 & 3 & 119 & $6(67 \%)$ & $181(60 \%)$ \\
\hline $1961-1965$ & 17 & 338 & 1 & 174 & $16(94 \%)$ & $164(49 \%)$ \\
\hline $1966-1970$ & 24 & 406 & 6 & 251 & $18(75 \%)$ & $155(38 \%)$ \\
\hline 1971-1975 & 71 & 755 & 42 & 563 & $29(41 \%)$ & $192(25 \%)$ \\
\hline $1976-1980$ & 273 & 1270 & 177 & 905 & $96(35 \%)$ & $365(29 \%)$ \\
\hline 1981-1985 & 519 & 1279 & 320 & 892 & $199(38 \%)$ & $387(30 \%)$ \\
\hline $1986-1990$ & 567 & 1045 & 416 & 785 & $151(27 \%)$ & $260(25 \%)$ \\
\hline Total & 1493 & 5951 & 966 & 3812 & $527(35 \%)$ & $2139(36 \%)$ \\
\hline
\end{tabular}

\section{Attrition/ $/^{2}$}

Attrition Rate

Women Men

.

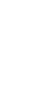




\section{TABLE 11}

\section{Attrition Rates of Women and Men Called in Alberta Between 1976-1990, as of May 1, 1991 ${ }^{1}$}

\section{Number Called Number In Good \\ Standing, 1991}

\begin{tabular}{|c|c|c|c|c|c|c|}
\hline $\begin{array}{l}\text { Year of } \\
\text { Call }\end{array}$ & Women & Men & Women & Men & Women & Men \\
\hline 1976 & 32 & 196 & 23 & 144 & $9(28 \%)$ & $52(27 \%)$ \\
\hline 1977 & 44 & 248 & 23 & 176 & $21(48 \%)$ & $72(29 \%)$ \\
\hline 1978 & 40 & 249 & 24 & 181 & $16(40 \%)$ & $68(27 \%)$ \\
\hline 1979 & 74 & 291 & 40 & 198 & $34(46 \%)$ & $93(32 \%)$ \\
\hline 1980 & 83 & 286 & 67 & 206 & $16(19 \%)$ & $80(28 \%)$ \\
\hline 1981 & 90 & 302 & 47 & 197 & $43(48 \%)$ & $105(35 \%)$ \\
\hline 1982 & 101 & 306 & 62 & 215 & $39(39 \%)$ & $91(30 \%)$ \\
\hline 1983 & 101 & 253 & 57 & 178 & $44(44 \%)$ & $75(30 \%)$ \\
\hline 1984 & 104 & 216 & 73 & 155 & $31(30 \%)$ & $61(28 \%)$ \\
\hline 1985 & 123 & 202 & 81 & 147 & $42(34 \%)$ & $55(27 \%)$ \\
\hline 1986 & 122 & 223 & 83 & 151 & $39(32 \%)$ & $72(32 \%)$ \\
\hline 1987 & 104 & 208 & 74 & 159 & $30(29 \%)$ & $49(24 \%)$ \\
\hline 1988 & 111 & 216 & 84 & 164 & $27(24 \%)$ & $52(24 \%)$ \\
\hline 1989 & 96 & 191 & 69 & 150 & $27(28 \%)$ & $41(21 \%)$ \\
\hline 1990 & 134 & 207 & 106 & 161 & $28(21 \%)$ & $46(22 \%)$ \\
\hline Total & 1359 & 3594 & 916 & 2582 & $443(33 \%)$ & $1012(28 \%)$ \\
\hline
\end{tabular}

\section{Attrition/ $/ 2$ \\ Attrition Rate}

Women Men

)

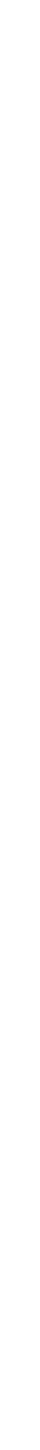




\section{TABLE 12}

\section{Number of Non-Practising Members Who Were Mailed Questionnaires And Number of Respondents, by Year of Call in Alberta}

\begin{tabular}{|c|c|c|c|c|c|c|}
\hline \multirow{2}{*}{$\begin{array}{l}\text { Year of } \\
\text { Call }\end{array}$} & \multicolumn{2}{|l|}{ Mail Out } & \multicolumn{2}{|c|}{ Respondents } & \multicolumn{2}{|c|}{ Response Rate' } \\
\hline & Women & Men & Women & Men & Women & Men \\
\hline Before 1978 & 7 & 69 & 1 & 36 & $14 \%$ & $52 \%$ \\
\hline $1978-1982$ & 26 & 25 & 16 & 14 & $62 \%$ & $56 \%$ \\
\hline $1983-1987$ & 51 & 22 & 27 & 12 & $53 \%$ & $55 \%$ \\
\hline 1988-1991 & 61 & 53 & 34 & 30 & $56 \%$ & $57 \%$ \\
\hline \multicolumn{7}{|l|}{ Missing } \\
\hline Total & 145 & 169 & 79 & 92 & $54 \%$ & $54 \%$ \\
\hline Median Year & 1987 & 1980 & 1987 & $1980^{2}$ & & \\
\hline
\end{tabular}

$1 \quad$ The overall response rate was $55 \%$ (174 responses to 314 questionnaires). Three of the respondents did not indicate whether they were male or female. Discounting these, the response rate was $54 \%$.

2 The median year of call for respondents called in 1978 or later was was 1988 , and the median year of call for respondents called before 1978 was 1959 . 


\section{TABLE 13}

\section{Present Employment of Respondents}

Women A-Men $\quad$ B-Men

\begin{tabular}{|c|c|c|c|}
\hline Self-Employed & $8(10.4 \%)$ & $10(17.9 \%)$ & $5(13.9 \%)$ \\
\hline Manager & $2(2.6 \%)$ & $2(3.6 \%)$ & $2(5.6 \%)$ \\
\hline Government Employee & $7(9.1 \%)$ & $3(5.4 \%)$ & $0(0 \%)$ \\
\hline Government Contract & $0(0 \%)$ & $1(1.8 \%)$ & $0(0 \%)$ \\
\hline Employee in a Business & $4(5.2 \%)$ & $7(12.5 \%)$ & $3(8.3 \%)$ \\
\hline Legal Education & $11(14.3 \%)$ & $3(5.4 \%)$ & $2(5.6 \%)$ \\
\hline Society or Union & $1(1.3 \%)$ & $1(1.8 \%)$ & $0(0 \%)$ \\
\hline Retired & $0(0 \%)$ & $1(1.8 \%)$ & $19(52.8 \%)$ \\
\hline Homemaker & $17(22.1 \%)$ & $1(1.8 \%)$ & $0(0 \%)$ \\
\hline Unemployed & $17(22.1 \%)$ & $19(33.9 \%)$ & $2(5.6 \%)$ \\
\hline Student & $2(2.6 \%)$ & $2(3.6 \%)$ & $1(2.8 \%)$ \\
\hline Other & $8(10.4 \%)$ & $6(10.7 \%)$ & $2(5.6 \%)$ \\
\hline Total & $77(100 \%)$ & $56(100 \%)$ & $36(100 \%)$ \\
\hline
\end{tabular}




\section{TABLE 14}

\section{Satisfaction With Aspects of Work When Last in Legal Profession}

\begin{tabular}{llllll} 
Very & & & & \multicolumn{3}{c}{$\begin{array}{l}\text { Very } \\
\text { Dissatisfied } \\
\text { Satisfied }\end{array}$} & & & \multicolumn{3}{c}{$\begin{array}{l}6 \\
1\end{array}$} & 2 & 3 & 4 & 5 & 6
\end{tabular}

Nature of Work

$\begin{array}{llllllll}\text { women }(\mathrm{N}=76) & 21 \% & 17 \% & 18 \% & 22 \% & 14 \% & 4 \% & 3 \% \\ 78+m e n(\mathrm{~N}=56) & 11 \% & 25 \% & 27 \% & 14 \% & 16 \% & 2 \% & 5 \% \\ \text { Pre-78 (N=35) } & 23 \% & 29 \% & 14 \% & 29 \% & 6 \% & 0 \% & 0 \%\end{array}$

Hours

$\begin{array}{lrrrrrrr}\text { women (N=76) } & 8 \% & 9 \% & 14 \% & 16 \% & 12 \% & 18 \% & 22 \% \\ \text { 78+men (N=56) } & 9 \% & 18 \% & 13 \% & 20 \% & 18 \% & 13 \% & 11 \% \\ \text { Pre-78 (N=34) } & 35 \% & 21 \% & 0 \% & 24 \% & 15 \% & 6 \% & 0 \%\end{array}$

Job Security

$\begin{array}{lrrrrrrl}\text { women (N=75) } & 8 \% & 13 \% & 11 \% & 23 \% & 3 \% & 15 \% & 28 \% \\ \text { 78+men (N=56) } & 13 \% & 11 \% & 9 \% & 14 \% & 13 \% & 20 \% & 21 \% \\ \text { Pre-78 (N=33) } & 36 \% & 18 \% & 9 \% & 24 \% & 6 \% & 0 \% & 6 \%\end{array}$

Money

$\begin{array}{lrrrrrrr}\text { women (N=76) } & 14 \% & 16 \% & 11 \% & 17 \% & 21 \% & 7 \% & 14 \% \\ 78+m e n(\mathrm{~N}=56) & 13 \% & 9 \% & 16 \% & 25 \% & 14 \% & 14 \% & 9 \% \\ \text { Pre-78 (N=34) } & 29 \% & 32 \% & 15 \% & 12 \% & 3 \% & 3 \% & 6 \%\end{array}$

Prestige of Work

$\begin{array}{lrrrrrrr}\text { women (N=75) } & 20 \% & 21 \% & 20 \% & 24 \% & 9 \% & 3 \% & 3 \% \\ 78+m e n(\mathrm{~N}=56) & 9 \% & 21 \% & 21 \% & 27 \% & 7 \% & 7 \% & 7 \% \\ \text { Pre-78 (N=34) } & 29 \% & 29 \% & 15 \% & 18 \% & 6 \% & 3 \% & 0 \%\end{array}$

Control Over Work

$\begin{array}{lrrrlrrr}\text { women (N=75) } & 4 \% & 11 \% & 12 \% & 21 \% & 12 \% & 20 \% & 20 \% \\ \text { 78+men (N=56) } & 7 \% & 14 \% & 13 \% & 5 \% & 29 \% & 20 \% & 13 \% \\ \text { Pre-78 (N=33) } & 39 \% & 21 \% & 9 \% & 15 \% & 6 \% & 6 \% & 3 \%\end{array}$

Opportunity for Advancement

$\begin{array}{lrrrrrrr}\text { women }(\mathrm{N}=73) & 7 \% & 8 \% & 12 \% & 23 \% & 22 \% & 14 \% & 14 \% \\ 78+m e n(\mathrm{~N}=56) & 11 \% & 5 \% & 16 \% & 23 \% & 20 \% & 13 \% & 13 \% \\ \text { Pre-78 (N=29) } & 24 \% & 28 \% & 7 \% & 24 \% & 7 \% & 3 \% & 7 \%\end{array}$

Employment Benefits

$\begin{array}{llllllll}\text { women }(\mathrm{N}=73) & 22 \% & 16 \% & 5 \% & 22 \% & 12 \% & 10 \% & 12 \% \\ 78+\text { men }(\mathrm{N}=56) & 13 \% & 20 \% & 11 \% & 18 \% & 13 \% & 16 \% & 11 \% \\ \text { Pre-78 (N=28) } & 36 \% & 25 \% & 14 \% & 18 \% & 0 \% & 0 \% & 7 \%\end{array}$

cont. 
Table 14 cont.

\begin{tabular}{|c|c|c|c|c|c|c|c|}
\hline \multicolumn{6}{|c|}{$\begin{array}{l}\text { Very } \\
\text { Satisfied }\end{array}$} & \multicolumn{2}{|c|}{$\begin{array}{l}\text { Very } \\
\text { Dissatisfied }\end{array}$} \\
\hline & 1 & 2 & 3 & 4 & 5 & 6 & 7 \\
\hline \multicolumn{8}{|l|}{ Female Colleagues } \\
\hline women $(\mathrm{N}=70)$ & $27 \%$ & $31 \%$ & $11 \%$ & $20 \%$ & $4 \%$ & $4 \%$ & $1 \%$ \\
\hline $78+\operatorname{men}(\mathrm{N}=52)$ & $23 \%$ & $25 \%$ & $21 \%$ & $19 \%$ & $4 \%$ & $6 \%$ & $2 \%$ \\
\hline Pre-78 $(\mathrm{N}=30)$ & $33 \%$ & $30 \%$ & $17 \%$ & $13 \%$ & $3 \%$ & $3 \%$ & $0 \%$ \\
\hline \multicolumn{8}{|l|}{ Male Colleagues } \\
\hline women $(\mathrm{N}=72)$ & $17 \%$ & $24 \%$ & $10 \%$ & $15 \%$ & $14 \%$ & $6 \%$ & $15 \%$ \\
\hline $78+\operatorname{men}(\mathrm{N}=55)$ & $16 \%$ & $24 \%$ & $22 \%$ & $25 \%$ & $7 \%$ & $2 \%$ & $4 \%$ \\
\hline Pre-78 (N=33) & $33 \%$ & $33 \%$ & $12 \%$ & $12 \%$ & $6 \%$ & $3 \%$ & $0 \%$ \\
\hline \multicolumn{8}{|l|}{ Administration } \\
\hline women $(\mathrm{N}=72)$ & $14 \%$ & $11 \%$ & $14 \%$ & $31 \%$ & $11 \%$ & $11 \%$ & $8 \%$ \\
\hline $78+\operatorname{men}(\mathrm{N}=55)$ & $9 \%$ & $15 \%$ & $18 \%$ & $22 \%$ & $20 \%$ & $7 \%$ & $9 \%$ \\
\hline Pre-78 (N=32) & $22 \%$ & $25 \%$ & $16 \%$ & $19 \%$ & $3 \%$ & $9 \%$ & $6 \%$ \\
\hline \multicolumn{8}{|l|}{ Support Staff } \\
\hline women $(\mathrm{N}=73)$ & $29 \%$ & $32 \%$ & $11 \%$ & $12 \%$ & $7 \%$ & $5 \%$ & $4 \%$ \\
\hline $78+\operatorname{men}(\mathrm{N}=54)$ & $19 \%$ & $31 \%$ & $20 \%$ & $19 \%$ & $6 \%$ & $2 \%$ & $4 \%$ \\
\hline Pre-78 (N=33) & $39 \%$ & $30 \%$ & $18 \%$ & $6 \%$ & $0 \%$ & $6 \%$ & $0 \%$ \\
\hline \multicolumn{8}{|c|}{ Balance With Personal Life } \\
\hline women $(\mathrm{N}=75)$ & $8 \%$ & $13 \%$ & $5 \%$ & $12 \%$ & $5 \%$ & $28 \%$ & $28 \%$ \\
\hline $78+\operatorname{men}(\mathrm{N}=55)$ & $11 \%$ & $9 \%$ & $20 \%$ & $16 \%$ & $22 \%$ & $9 \%$ & $13 \%$ \\
\hline Pre-78 $(\mathrm{N}=34)$ & $35 \%$ & $21 \%$ & $9 \%$ & $18 \%$ & $3 \%$ & $15 \%$ & $0 \%$ \\
\hline
\end{tabular}




\section{TABLE 15}

\section{Reasons Why Respondents Are Not Practising Law}

\section{Very \\ Relevant}

Not Relevant

at All

Better Position Outside Law

$\begin{array}{lccccccc}\text { women (N=69) } & 20 \% & 9 \% & 1 \% & 9 \% & 4 \% & 10 \% & 46 \% \\ 78+\text { men (N=49) } & 20 \% & 10 \% & 6 \% & 6 \% & 4 \% & 8 \% & 45 \% \\ \text { Pre-78 (N=16) } & 25 \% & 6 \% & 6 \% & 6 \% & 0 \% & 6 \% & 50 \%\end{array}$

Higher Income Outside Law

$\begin{array}{lccccccc}\text { women }(\mathrm{N}=70) & 10 \% & 0 \% & 3 \% & 4 \% & 6 \% & 6 \% & 71 \% \\ 78+m e n(\mathrm{~N}=49) & 8 \% & 6 \% & 4 \% & 6 \% & 8 \% & 10 \% & 57 \% \\ \text { Pre-78 (N=14) } & 14 \% & 0 \% & 7 \% & 0 \% & 0 \% & 21 \% & 57 \%\end{array}$

Lack of Flexibility in Firm

$\begin{array}{lrrrrrrr}\text { women (N=73) } & 30 \% & 14 \% & 16 \% & 4 \% & 7 \% & 7 \% & 22 \% \\ 78+m e n(\mathrm{~N}=50) & 10 \% & 6 \% & 16 \% & 6 \% & 20 \% & 8 \% & 34 \% \\ \text { Pre-78 (N=12) } & 0 \% & 0 \% & 0 \% & 17 \% & 8 \% & 17 \% & 58 \%\end{array}$

Stressful Nature of Work $\begin{array}{llllllll}\text { women (N=72) } & 31 \% & 8 \% & 22 \% & 8 \% & 6 \% & 8 \% & 17 \%\end{array}$

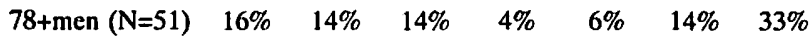
$\begin{array}{llllllll}\text { Pre-78 }(\mathrm{N}=17) \quad 18 \% & 0 \% & 29 \% & 29 \% & 6 \% & 6 \% & 12 \%\end{array}$

Adversarial Nature of Work

$\begin{array}{lrrrrrrr}\text { women (N=69) } & 14 \% & 13 \% & 9 \% & 10 \% & 6 \% & 13 \% & 35 \% \\ 78+m e n(\mathrm{~N}=52) & 21 \% & 10 \% & 15 \% & 10 \% & 6 \% & 13 \% & 25 \% \\ \text { Pre-78 (N=15) } & 13 \% & 0 \% & 20 \% & 20 \% & 13 \% & 7 \% & 27 \%\end{array}$

Law Society Fees/Insurance

$\begin{array}{lrrrrrrr}\text { women (N=69) } & 9 \% & 12 \% & 13 \% & 9 \% & 1 \% & 10 \% & 46 \% \\ 78+m e n(\mathrm{~N}=51) & 10 \% & 10 \% & 12 \% & 12 \% & 8 \% & 10 \% & 39 \% \\ \text { Pre-78 (N=17) } & 24 \% & 0 \% & 12 \% & 12 \% & 12 \% & 29 \% & 12 \%\end{array}$

Loss of Employment

$\begin{array}{lrllllll}\text { women (N=69) } & 25 \% & 6 \% & 0 \% & 4 \% & 1 \% & 7 \% & 57 \% \\ 78+m e n(\mathrm{~N}=50) & 34 \% & 2 \% & 0 \% & 6 \% & 6 \% & 2 \% & 50 \% \\ \text { Pre-78 (N=16) } & 25 \% & 0 \% & 0 \% & 13 \% & 0 \% & 6 \% & 56 \%\end{array}$

cont. 
TABLE 15 cont.

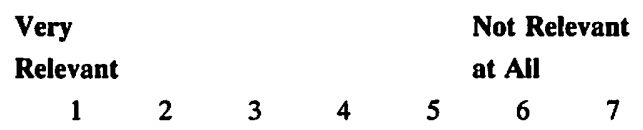

Lack Opportunity for Advancement

$\begin{array}{lrrrrrrr}\text { women }(\mathrm{N}=70) & 10 \% & 4 \% & 3 \% & 9 \% & 7 \% & 14 \% & 53 \% \\ 78+\text { men }(\mathrm{N}=50) & 6 \% & 10 \% & 6 \% & 12 \% & 14 \% & 8 \% & 44 \% \\ \text { Pre-78 (N=14) } & 0 \% & 7 \% & 7 \% & 0 \% & 0 \% & 14 \% & 71 \%\end{array}$

Child Care Commitments

$\begin{array}{lrrrrrrr}\text { women (N=74) } & 34 \% & 1 \% & 7 \% & 0 \% & 0 \% & 1 \% & 57 \% \\ \text { 78+men (N=50) } & 4 \% & 0 \% & 4 \% & 2 \% & 0 \% & 0 \% & 90 \% \\ \text { Pre-78 (N=14) } & 0 \% & 0 \% & 0 \% & 0 \% & 0 \% & 14 \% & 86 \%\end{array}$

\section{Spouse's Career}

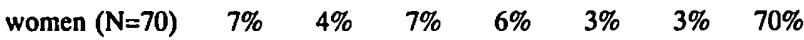

$78+$ men $(\mathrm{N}=51) \quad 6 \% \quad 2 \% \quad 2 \% \quad 0 \% \quad 2 \% \quad 6 \% \quad 82 \%$

Pre-78 $(\mathrm{N}=14) \quad 0 \% \quad 0 \% \quad 0 \% \quad 0 \% \quad 0 \% \quad 14 \% \quad 86 \%$

Hours Demanded By Practice

$\begin{array}{lrrrrrrr}\text { women }(\mathrm{N}=73) & 41 \% & 21 \% & 11 \% & 3 \% & 3 \% & 5 \% & 16 \% \\ 78+m e n(\mathrm{~N}=52) & 12 \% & 19 \% & 10 \% & 12 \% & 6 \% & 12 \% & 31 \% \\ \text { Pre-78 (N=16) } & 6 \% & 13 \% & 19 \% & 13 \% & 0 \% & 6 \% & 44 \%\end{array}$

Low Pay/Income

$\begin{array}{lrrrrrrr}\text { women (N=70) } & 9 \% & 11 \% & 3 \% & 14 \% & 6 \% & 7 \% & 50 \% \\ 78+m e n(\mathrm{~N}=49) & 8 \% & 12 \% & 14 \% & 10 \% & 6 \% & 10 \% & 39 \% \\ \text { Pre-78 (N=14) } & 0 \% & 0 \% & 14 \% & 7 \% & 0 \% & 14 \% & 64 \%\end{array}$

\section{Bored}

$\begin{array}{lrrrrrrr}\text { women (N=69) } & 9 \% & 3 \% & 9 \% & 16 \% & 4 \% & 6 \% & 54 \% \\ 78+m e n(\mathrm{~N}=48) & 4 \% & 15 \% & 6 \% & 17 \% & 8 \% & 13 \% & 37 \% \\ \text { Pre-78 (N=13) } & 8 \% & 8 \% & 8 \% & 0 \% & 23 \% & 8 \% & 46 \%\end{array}$

Felt Burnt Out

$\begin{array}{lccccccc}\text { women }(\mathrm{N}=70) & 17 \% & 13 \% & 13 \% & 13 \% & 1 \% & 3 \% & 40 \% \\ 78+m e n(\mathrm{~N}=48) & 10 \% & 8 \% & 6 \% & 10 \% & 4 \% & 10 \% & 50 \% \\ \text { Pre-78 (N=16) } & 31 \% & 25 \% & 6 \% & 13 \% & 19 \% & 0 \% & 6 \%\end{array}$

Exposure to Liability

$\begin{array}{lrrrrrrr}\text { women }(\mathrm{N}=70) & 7 \% & 4 \% & 10 \% & 9 \% & 6 \% & 10 \% & 54 \% \\ 78+m e n(\mathrm{~N}=48) & 4 \% & 10 \% & 10 \% & 10 \% & 13 \% & 8 \% & 44 \% \\ \text { Pre-78 (N=14) } & 7 \% & 7 \% & 7 \% & 29 \% & 14 \% & 7 \% & 29 \%\end{array}$

cont. 
TABLE 15 cont.

\begin{tabular}{lllllcc}
$\begin{array}{l}\text { Very } \\
\text { Relevant }\end{array}$ & & & & \multicolumn{3}{c}{$\begin{array}{c}\text { Not Relevant } \\
\text { at All }\end{array}$} \\
1 & 2 & 3 & 4 & 5 & 6 & 7
\end{tabular}

Wanted to Use Different Skills

$\begin{array}{lrrrrrrr}\text { women (N=68) } & 15 \% & 9 \% & 15 \% & 10 \% & 1 \% & 6 \% & 44 \% \\ \text { 78+men (N=49) } & 16 \% & 18 \% & 12 \% & 14 \% & 8 \% & 8 \% & 22 \% \\ \text { Pre-78 (N=16) } & 50 \% & 13 \% & 13 \% & 6 \% & 0 \% & 0 \% & 19 \%\end{array}$

Cannot Find a Job

$\begin{array}{lrrrrrrr}\text { women }(\mathrm{N}=68) & 25 \% & 3 \% & 3 \% & 9 \% & 7 \% & 6 \% & 47 \% \\ 78+m e n(\mathrm{~N}=49) & 37 \% & 6 \% & 2 \% & 4 \% & 6 \% & 0 \% & 45 \% \\ \text { Pre-78 (N=13) } & 8 \% & 8 \% & 0 \% & 8 \% & 0 \% & 0 \% & 77 \%\end{array}$




\section{TABLE 16}

\section{Perception of Gender Bias in the Legal Profession}

Bias Against Women

There is none

$0(0 \%)$

$18(23.4 \%)$

Exists, but is not

widespread

$25(44.6 \%)$

$18(50.0 \%)$

Widespread, but subtle and

difficult to detect

$38(49.4 \%)$

$17(30.4 \%)$

$8(22.2 \%)$

Widespread and

readily apparent

$19(24.7 \%)$

$5(8.9 \%)$

$1(2.8 \%)$

No response

$2(2.6 \%)$

$3(5.4 \%)$

$\underline{2(5.6 \%)}$
$77(100 \%)$

Total

Bias Against Men

Women

$59(76.6 \%)$

$26(46.4 \%)$

$20(55.6 \%)$

There is none

$15(19.5 \%)$

$23(41.1 \%)$

$14(38.9 \%)$
$15(19.5 \%)$

Widespread, but subtle and

difficult to detect

$1(1.3 \%)$

readily apparent

$1(1.3 \%)$

No response

$1(1.3 \%)$

$77(100 \%)$

Total
Widespread and
$3(5.4 \%)$

$2(3.6 \%)$

$2(3.6 \%)$

$56(100 \%)$
$36(100 \%)$

\section{Pre-78 Men}




\section{TABLE 17}

\section{Nature of Bias in the Legal Profession ${ }^{1}$}

\begin{tabular}{|c|c|c|c|c|}
\hline Nature of Bias & $\begin{array}{l}\text { Against } \\
\text { Women }\end{array}$ & $\begin{array}{l}\text { Against } \\
\text { Men }\end{array}$ & $\begin{array}{l}\text { Against } \\
\text { Both }\end{array}$ & $\begin{array}{l}\text { No Bias/ } \\
\text { No Response } 2\end{array}$ \\
\hline
\end{tabular}

Lawyers not giving appropriate

weight to opinions

$\begin{array}{lrrrr}\text { women } & 55.8 \% & 0 \% & 0 \% & 44.2 \% \\ 78+\text { men } & 28.6 \% & 0 \% & 5.4 \% & 66.1 \% \\ \text { Pre-78 men } & 33.3 \% & 0 \% & 0 \% & 66.7 \%\end{array}$

career advancement

$\begin{array}{lrrrr}\text { women } & 81.8 \% & 0 \% & 0 \% & 18.2 \% \\ 78+\text { men } & 60.7 \% & 3.6 \% & 3.6 \% & 32.1 \% \\ \text { Pre-78 men } & 38.9 \% & 0 \% & 2.8 \% & 58.3 \%\end{array}$

access to clients

$\begin{array}{lrrrr}\text { women } & 59.7 \% & 0 \% & 0 \% & 40.3 \% \\ 78+\text { men } & 23.2 \% & 1.8 \% & 3.6 \% & 71.4 \% \\ \text { Pre-78 men } & 16.7 \% & 0 \% & 2.8 \% & 80.6 \%\end{array}$

assignment of files/work

$\begin{array}{lrrrr}\text { women } & 58.4 \% & 1.3 \% & 0 \% & 40.3 \% \\ 78+\text { men } & 25.0 \% & 0 \% & 8.9 \% & 66.1 \% \\ \text { Pre-78 men } & 13.9 \% & 0 \% & 2.8 \% & 83.3 \%\end{array}$

setting hourly rates

$\begin{array}{lrrrr}\text { women } & 23.4 \% & 1.3 \% & 0 \% & 75.3 \% \\ 78+\text { men } & 8.9 \% & 0 \% & 0 \% & 91.1 \% \\ \text { Pre-78 men } & 8.3 \% & 0 \% & 2.8 \% & 88.9 \%\end{array}$

remuneration

$\begin{array}{lrrrr}\text { women } & 51.9 \% & 0 \% & 0 \% & 48.1 \% \\ 78+\text { men } & 26.8 \% & 0 \% & 1.8 \% & 71.4 \% \\ \text { Pre-78 men } & 27.8 \% & 0 \% & 2.8 \% & 69.4 \%\end{array}$

cont.

1 The percentages of women and men who identified each type of bias are of the 77 women, $5678+$ men, and 36 pre- 78 men who responded to the survey.

$2 \quad$ "No response" includes all those who did not indicate a form of bias against women or men. Some of these respondents may simply have chosen not to answer the question, and therefore the perception of gender bias could be more widespread than would appear from this Table. 
TABLE 17 cont.

$\begin{array}{lrrrr}\text { Nature of Bias } & \begin{array}{l}\text { Against } \\ \text { Women }\end{array} & \begin{array}{l}\text { Against } \\ \text { Men }\end{array} & \begin{array}{l}\text { Against } \\ \text { Both }\end{array} & \begin{array}{l}\text { No Bias/ } \\ \text { No Response }\end{array} \\ \begin{array}{l}\text { hiring } \\ \quad \text { women }\end{array} & 57.1 \% & 1.3 \% & 3.9 \% & 37.7 \% \\ 78+\text { men } & 33.9 \% & 8.9 \% & 8.9 \% & 48.2 \% \\ \text { Pre-78 men } & 27.8 \% & 0 \% & 2.8 \% & 69.4 \%\end{array}$

attaining partnership

$\begin{array}{lrrrr}\text { women } & 75.3 \% & 0 \% & 0 \% & 24.7 \% \\ 78+\text { men } & 51.8 \% & 0 \% & 5.4 \% & 42.9 \% \\ \text { Pre-78 men } & 38.9 \% & 0 \% & 2.8 \% & 58.3 \%\end{array}$

access to managerial positions

$\begin{array}{lrrrr}\text { women } & 44.2 \% & 0 \% & 0 \% & 55.8 \% \\ 78+\text { men } & 25.0 \% & 3.6 \% & 1.8 \% & 69.6 \% \\ \text { Pre-78 men } & 33.3 \% & 0 \% & 0 \% & 66.7 \%\end{array}$

opportunity to appear in court

$\begin{array}{lrrrr}\text { women } & 11.7 \% & 0 \% & 1.3 \% & 87.0 \% \\ 78+\text { men } & 7.1 \% & 0 \% & 0 \% & 92.9 \% \\ \text { Pre-78 men } & 5.6 \% & 0 \% & 0 \% & 94.4 \%\end{array}$

judicial attitudes

$\begin{array}{lrrrr}\text { women } & 44.2 \% & 0 \% & 0 \% & 55.8 \% \\ 78+\text { men } & 23.2 \% & 0 \% & 1.8 \% & 75.0 \% \\ \text { Pre-78 men } & 22.2 \% & 0 \% & 2.8 \% & 75.0 \%\end{array}$

unwanted sexual advances

$\begin{array}{lrrrr}\text { women } & 29.9 \% & 1.3 \% & 1.3 \% & 67.5 \% \\ 78+\text { men } & 23.2 \% & 0 \% & 3.6 \% & 73.2 \% \\ \text { Pre-78 men } & 19.4 \% & 0 \% & 0 \% & 80.6 \%\end{array}$

unwanted teasing, jokes

$\begin{array}{lrrrr}\text { women } & 46.8 \% & 0 \% & 1.3 \% & 51.9 \% \\ 78+\text { men } & 37.5 \% & 0 \% & 3.6 \% & 58.9 \% \\ \text { Pre-78 men } & 22.2 \% & 0 \% & 0 \% & 77.8 \%\end{array}$

nature of office/firm functions

$\begin{array}{lrrrr}\text { women } & 40.3 \% & 1.3 \% & 2.6 \% & 55.8 \% \\ 78+\text { men } & 19.6 \% & 0 \% & 8.9 \% & 71.4 \% \\ \text { Pre-78 men } & 16.7 \% & 0 \% & 0 \% & 83.3 \%\end{array}$

cont. 


\section{TABLE 17 cont.}

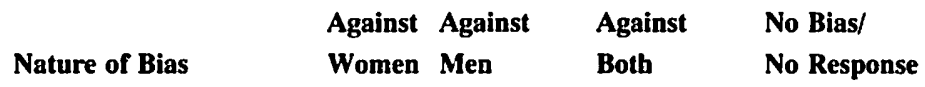

nature of promotional functions

$\begin{array}{lrrrr}\text { women } & 37.7 \% & 0 \% & 0 \% & 62.3 \% \\ 78+\text { men } & 14.3 \% & 1.8 \% & 1.8 \% & 82.1 \% \\ \text { Pre-78 men } & 13.9 \% & 0 \% & 0 \% & 86.1 \%\end{array}$

judicial appointments

$\begin{array}{lrrrr}\text { women } & 13.0 \% & 5.2 \% & 1.3 \% & 80.5 \% \\ 78+\text { men } & 16.1 \% & 10.7 \% & 0 \% & 73.2 \% \\ \text { Pre-78 men } & 8.3 \% & 5.6 \% & 5.6 \% & 80.6 \%\end{array}$

lack of accommodation

for family commitments

$\begin{array}{lrrrr}\text { women } & 59.7 \% & 1.3 \% & 13.0 \% & 26.0 \% \\ 78+\text { men } & 21.4 \% & 3.6 \% & 17.9 \% & 57.1 \% \\ \text { Pre-78 men } & 27.8 \% & 0 \% & 2.8 \% & 69.4 \%\end{array}$




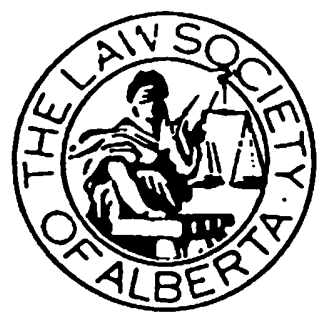

\section{Survey of Inactive Members of The Law Society of Alberta}

1. How are you primarily employed?
$\square$ self-employed or owner of a business
a manager
a government employee
a government (contract)
a employee in a business
a legal education
a society or union
a retired
a homemaker
a unemployed
a student
other (please specify)

2. If you are working, are you working
$\square$ full time
口 full time, but secking part time or job sharing
$\square$ part time or job sharing
a part time or job sharing, but seeking full time

3. If you are working, is your work
a unrelated to your legal training
a somewhat related to your legal training
a very related to your legal training

4. How long have you practised law in all jurisdictions (do not include articles)?

- years

5. When were you called to the Bar in Alberta? 19

6. Since your call in Alberta, how long in total have you spent not pratising law and at the same time looking for a position in practice?

— years
7. Since your call in Alberta, how many different jobs have you had in each of the following categories, excluding moves within the same firm or organization:

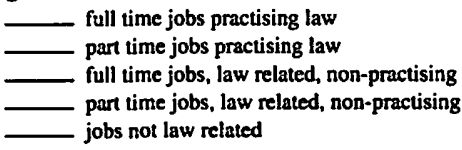

8. How many of the "practising law" jobs in Question 7 ended for reasons other than your choice?

- jobs

If any of your "practising law" jobs ended for reasons other than your choice and you wish to elaborate on the circumstances, please a separate page and identify your response as relating to Question 8.

9. Would you prefer to be practising law at this time?
$\square$ yes
口 no

10. If you would prefer to be practising law, which of the following positions would you prefer?

$\square$ sole practitioner on own

$\square$ office sharing with other practitioner(s)

associate in or employee of a law firm

- partner in law firm

D government lawyer (employee)

D government lawyer (contract)

- corporate counsel

a community law office/public interest advocste

other (please specify) 
11. How relevant are the following factors in explaining why you are not practising law at this time?

betuer position outside law
higher income outside law
lack of flexibility in firm
stressful nature of work
adversarial nature of work
law society fees/insurance
loss of employment
lack of opportunity for
advancement
child care commitments
spousc's career
hours demanded by practice
low payfincome
bored
felt "burnt out"
exposure to liability
wanted to use different skills
cannot find a job

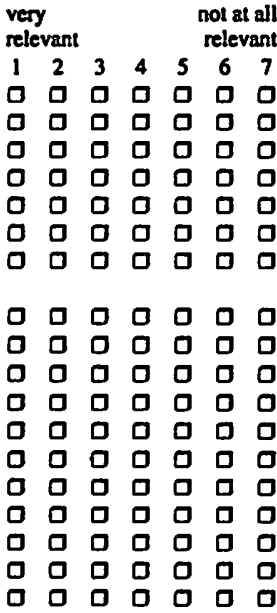

If you wish to expand on any of these factors, please use a separate page and identify your response as related to Question 11.

12. How were you last employed in the legal profession?
a sole practitioner on own
- office sharing with other practitioner(s)
D associate in or employee of a law firm
a partner in a law firm
D government lawyer (cmployee)
a government lawyer (contract)
- industry/corporate counsel
Q legal cducation
a society or union
口 contract research
- community law office/public interest advocate
- articling student
o other (please specify)

13. How satisfied were you with the following aspects of your work when you weze last employed in the legal profession?

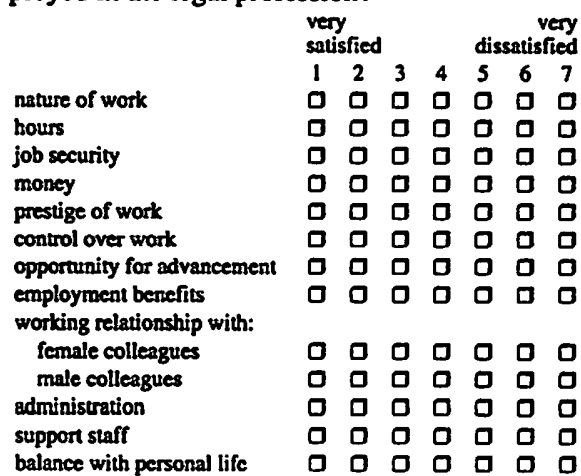

14. In what year did you last practise law in Alberta?

19

15. What is your perception of gender bias or discrimination against women in the legal profession in Alberta today?
(D) there is none
$\square$ it exists, but is not widespread
D it is widespread, but subtle and difficult to deiect
$\square$ it is widespread and readily apparent

16. What is your perception of gender bias or discrimination against men in the legal profession in Alberta today?
a there is none
- it exists, but is not widespread
a it is widespread, but sublle and difficult to deteci
a it is widespread and readily apparent

17. If you think there is gender bias or discrimination against women or men in the legal profession, how would you categorize it? (Check as many as appropriate.)

$$
\text { bias against: }
$$

\begin{tabular}{|c|c|c|}
\hline $\boldsymbol{0}$ & 口 & $\begin{array}{l}\text { other lawyers not giving appropriate } \\
\text { weight to opinions }\end{array}$ \\
\hline ם & $\mathbf{\square}$ & career advancement \\
\hline ם & $\mathbf{0}$ & access to clients \\
\hline ם & $\mathbf{0}$ & assignment of files/work \\
\hline ם & $\overrightarrow{0}$ & setting hourly rates \\
\hline 口 & $\bar{\square}$ & remuneration \\
\hline $\boldsymbol{0}$ & 口 & hiring \\
\hline 0 & ם & attaining partnership \\
\hline ם & $\mathbf{0}$ & access to managerial positions \\
\hline 口 & ס & opportunity to appear in coun \\
\hline 0 & ם & judicial attitudes \\
\hline$\square$ & 口 & unwanted sexual advances \\
\hline ם & ם & $\begin{array}{l}\text { unwanted teasing, jokes or comments of } \\
\text { a sexual nature }\end{array}$ \\
\hline 口 & ם & the nature of office/fim functions \\
\hline 0 & 口 & the nature of promotional functions \\
\hline$\square$ & ם & judicial appointments \\
\hline$\square$ & 0 & $\begin{array}{l}\text { lack of accommodation for family } \\
\text { commitments }\end{array}$ \\
\hline ם & 口 & other (please specify) \\
\hline
\end{tabular}

If you wish to explain or elaborate on any of the above forms of bias, please use a separate page and identify your response as relating to Question 17.

18. What is the size of the community within which you work? (If you are not working, what is the size of the community within which you live?)
(D) 100,000 or more
( $50,000-99,999$
a $10,000-49,999$
口 Under 10,000 
19. What effect did not practising law have on your income?

$\square$ increased my income by $s$ , 000

口 decreased my income by $\$$ , 000

Q income remained the same

$\square$ don't know

20. Are you

a male

0 female

21. In what year were you born? 19

22. Have you personally experienced discrimination while seeking employment as, or during the course of your employment as a lawyer, on the basis of any of the following: (Check as many as applicable.)

sex
colour or race
disability
age
marital status
sexual orientation
parental status
other (please specify)
by other lawyers by clients you experienced any problems and wish to elaborate on the circumstances, please use a separate page and identify your response as relating to Question 22.

23. Are you, by virtue of your colour or race, in a visible minority?
$\square$ yes
( no

24. For the purpose of employment, do you consider yourself disadvantaged by reason of a persistent disability?
$\square$ yes
ロ no

25. Are you living in a married or equivalent relationship?
$\square$ yes
a no

26. If you are living in a married or equivalent relationship, is your spouse:

a employed full time

- employed part time

not employed

27. How many hours per week do you usually spend on household chores other than child care?
28. Which one of the following best describes the kind of work your parents usually did while you were growing up? (If you lived with a guardian for most of these years, please describe their kind of work instead.)

owner of a business with $>10$ employees
owner of a business with $1-10$ employees
self-employed, no employees
manager
employee
retired
homemaker
student
unemployed
other (please specify)

Mother Father

口 $\square$

$\square \quad 0$

$0 \quad 0$

$\square \quad \square$

$\square$ 口

$\square \quad \square$

$\square$ 口

0 व

$\square \quad \square$

other (please specify) — $\square \square$

29. Are or were any of the following of your relatives lawyers:
a grandmother
G grandfather
a mother
a brother
a father
口 sister
a spouse

30. Did you enter law school with the intention of practising law?
$\square$ yes
$\square$ no
a was not sure

31. Are you presently looking for a position in the practice of law?

口 yes

no

32. If you are looking for a position in the practice of law, are you encountering any problems in your search?

$\square$ yes

(

If you are encountering problems and wish to elaborate on them, please use a separate page and identify your response as relating to Question 32 .

33. If you could "do it over again", would you become a lawyer?
$\square$ yes
口 no

34. Should the Law Society take any action to facilitate or encourage members to retain their status as active members?
$\square$ yes
a no
a don't know

If you think the Law Society should take some action and wish to elaborate on this, please use a separate page and identify your response as relating to Question 34. 
35. Are changes to the legal profession necessary to better accommodate the needs of people such as you?
$\square$ yes
口 no
a don't know

If you think changes are needed and wish to elaborate, please use a separate page and identify your response as relating to Question 35 .

\section{QUESTIONS 36-43 ARE FOR THOSE WHO ARTICLED IN ALBERTA DURING THE PERIOD 1980-1991 INCLUSIVE. If you are not in this category, please go to the next section of the Survey.}

36. How many firms did you apply to for articles? firms

37. How many firms were prepared to interview you for articles? - firms

38. Did you experience any problems finding articles on the basis of:
a sex
a marital status
a colour or race
a sexual orientation
a disability
$\square$ age
a parental status
$\square$ other (please specify)

If you experienced any problems and wish to elaborate on the circumstances, please use a separate page and identify your response as relating to Question 38.

39. Did you get your first or second choice in articling positions?
$\square$ first choice
$\square$ neither first nor second
$\square$ second choice

40. Did you stay on with the firm you articled with for more than one year after articles?

$\square$ yes

$\square$ no

41. a) If you left your firm within one year of articles, was it by choice?
口 yes
口 no

41. b) If you left within a year, did you find another law-related position?

D yes
42. If you left your firm within one year of articles and found another law-related position:

a) how long did it take you to find your new position?

months

b) how satisfied were you with your new position?

\begin{tabular}{lcccccc}
\multicolumn{2}{c}{ very satisfied } & & \multicolumn{3}{c}{ very dissatisfied } \\
I & 2 & 3 & 4 & 5 & 6 & 7 \\
$\square$ & $\square$ & $\square$ & $\square$ & $\square$ & $\square$ & $\square$
\end{tabular}

43. Approximately, where did you rank in your graduating class?
a $\operatorname{lop} 1 / 4$
$\square$ second $1 / 4$
a fourth $1 / 4$
third $1 / 4$
व don'l know

THE REMAINING QUESTIONS ARE FOR THOSE WITH CHILDREN. If you do not have children, you have completed this Survey. Thank you for participating in this Survey.

44. How many children do you have? children

45. If you have children who require care (including feeding, supervision, attendance at sporting and school events, etc.):

a) what proportion of responsibility for that care is borne by each of the following:

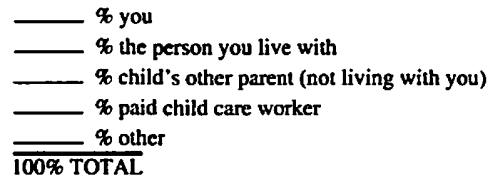

b) how many hours per week do you spend on this care?

_ hours per week

46. If you have been involved in making child care arrangements, how much difficulty have you experienced?

\begin{tabular}{lllllll} 
none & & & & \multicolumn{3}{c}{ a great deal } \\
1 & 2 & 3 & 4 & 5 & 6 & 7 \\
$\square$ & $\square$ & $\square$ & $\square$ & 0 & $\square$ & $\square$
\end{tabular}


THE REMAINING QUESTIONS ARE FOR THOSE WHO HAVE BECOME PARENTS SINCE 1985, AND WERE AT THE TIME ARTICLING OR CALLED TO THE ALBERTA BAR. If you do not come within this description, you have completed this Survey. Thank you for your participation.

47. How many children have you had since 1985 ? children

48. Did you experience any of the following as a result of having children?
a loss of seniority
a delay in promotion
a loss of office space
a pressure to return to work during parental leave
a pressure to work while on parental leave
a unreasonable work load following parental leave
a lesting of commitment to work
a loss of clients
口 loss of job
a difficulty in obraining leave
a difficulty in obtaining flexible hours or part time work
a loss of income
a stress from competing demands
a other (please specify)

49. When was your last child born?

19

50. a) How much maternity or paternity leave did you take when your last child was born?

- weeks

b) If you took leave, how sufficient ws it?

\begin{tabular}{ccccccc} 
very sufficient & & & \multicolumn{2}{c}{ very insufficient } \\
1 & 2 & 3 & 4 & 5 & 6 & 7 \\
$\square$ & $\square$ & $\square$ & $\square$ & $\square$ & $\square$ & $\square$
\end{tabular}

If your leave was insufficient and you wish to elaborate on the circumstances, please use a separate page and identify your response as relating to Question $\mathbf{5 0 .}$

51. If you took parental leave when your last child was born, what percentage of your regular pre-leave income did payments from each of the following sources represent?

\footnotetext{
\% Unemployment Insurance
\% disability insurance
\% payment from firm
\% other (please specify)
(Figures will add up to $100 \%$ ONLY if you received $100 \%$ (Figures will add up to $100 \%$
of your pre-leave income).
}

If you wish to elaborate on any aspect of this Survey, please do so in the space provided, or on a separate page.

Response Relating to Question

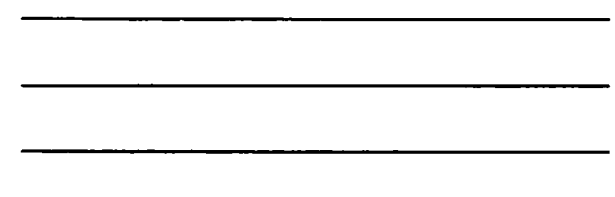

